\title{
PROGRESS PERFORMANCE REPORT
}

OF

\author{
CLEAN USES OF FOSSIL FUELS
}

\section{USDOE/EPSCOR Traineeship Grant \\ U.S. Department of Energy Office of Energy Research}

\author{
BY \\ Kentucky EPSCoR Committee \\ and \\ DOE/EPSCOR Subcommittee
}

\section{DISCLAIMER}

This report was prepared as an account of work sponsored by an agency of the United States Government. Neither the United States Government nor any agency thereof, nor any of their employees, makes any warranty, express or implied, or assumes any legal liability or responsibility for the accuracy, completeness, or usefulness of any information, apparatus, product, or process disclosed, or represents that its use would not infringe privately owned rights. Reference herein to any specifrc commercial product, process, or service by trade name, trademark, manufacturer, or otherwise does not necessarily constitute or imply its endorsement, recommendation, or favoring by the United States Government or any agency thereof. The views and opinions of authors expressed herein do not necessarily state or reflect those of the United States Government or any agency thereof. 
I. EXECUTIVE SUMMARY ............... 1

II. PROJECT DESCRIPTION . . . . . . . . . . . 2

A. Progress to Date . . . . . . . . . 2 2

1. Competition and Awarding of Traineeships . 3

2. Identification and summaries

of Traineeships Research Areas . . . . 7

3. Practicum Arrangements and Plans ..... 21

B. Current Problems and Unusual Developments . . 23

C. Summary of Effort in succeeding Funding Period, 23

III. BUDGET ............... . 26

A. Budget Explanation .......... . 27

B. Detailed Budget. ............. 28

APPENDICES

I. MEMBERS - KY EPSCOR COMMITTEE AND

DOE $\cdots$ ESSCOR SUBCOMMITTEE . . . . . . . . . 31

II. RESUMES OF CHAIR, KY EPSCOR COMMITTEE

PROJECT DIRECTOR,

CHAIR KY DOE/EPSCOR SUBCOMMITTEE ...... . 35

III. TRAINEESHIP ANNOUNCEMENT AND APPLICATION FORM . . 42

IV. TRAINEESHIP REVIEW PANEL . . . . . . . . . 46

V. RESUMES OF FACULTY MENTORS .......... 48

VI. MEMORAVDIM OF AGREEMENT

BETWEEI KSTC AND KY DOE/EPSCOR COMMITTEE • • • 69 


\section{EXECETIVE GONAARY}

A one-year USDOE/EPSCOR Traineeship Grant, entitled "clean Uses of Fossil Fuels", was awarded to the Kentucky EPSCOR Committee. in september 2991 and administered through the the DOE/EPSCOR subcommittee. From this grant, ten Traineeships were awarded to doctoral students who are enrolled or accepted into graduate Programs at either the University of Kentucky or the University of Louisville. The disciplines of these students include Biology, Chemical Engineering, Chemistry, Geological sciences, and Physics.

The methods used for a statewide proposal solicitation and to award the Traineeships are presented. The review panel and Kertucky DOE/EPSCOR subcomittee involved in awarding the Traineeships are described. A summary of the proposed research to be performed within these awards is presented, along with a description of the qualifications of the faculty and students who proposed projects.

Future efforts to increase participation in rraineeship proposals for the succeeding funding period are outlined. These efforts are an outcome of discussions held since the awarding of the grant from the USDOE and the experience gained in establishing and administering this initial one year grant. Two notable features for the future two year award include:

a) the participation of the graduate students in the Oak Ridge Associated Universities (ORAU) Graduate student Research Participation program (GRSP); and b) a direct link of the Kentucky DOE/EPSCOR program with the Kentucky science and Technology council (KSTC). 


\section{PROTECT DEBCRIPTION}

\section{A. Progress to Date}

The Kentucky DOE/EPSCOR Program was successful in obtaining a USDOE/EPSCOR Traineeship Grant in september 1991. This $\$ 250,000$ grant was used to award ten doctoral traineeships to students who either were accepted in Graduate school and working on a PhD dissertation or who had applied to become graduate students at the University of Kentucky and University of Louisville - the two Ph.D. science and engineering granting universities within the commonwealth of Kentucky. The awards included an $\$ 18,000$ stipend, $\$ 2,000$ for tuition, and $\$ 5,000$ for travel and supplies during the student's research.

The Traineeship awards were to focus on the "clean Uses of Fossil Fuels" and to include the four subtheme or topical research areas: a) Carbon Based Materials; b) Catalysis; c) climate Modeling; and d) Environmental Impact and Bioremediation. These areas are considered important for the future needs of industry and manpower within the commonwealth and the US. over 170 million tons of coal per year are produced within the commonwealth of Kentucky (\$2 producer in the United states), with coal and energy/energyrelated business its major economic base. Hence, the Kentucky DOE/EPSCOF Program is designed as a state-wide effort to enhance the capabilities of the commonwealth to develop science and engineering manpower in energy-related areas and to conduct nationally competitive energy-related research. The docioral traineeships build upon existing expertise in the commonwealth and provide enhanced research opportunities at higher education institutions, USDOE laboratories, and energy-related industries. 
It will also improve the human resource base of the commonwealth and strengthen and enhance wcience and engineering programs in energy-related research.

1. Competition and Awarding of Traineeships

The Kentucky EPSCOR Committee (See Appendix I) coordinates and administers all EPSCOR programs in the state. A DOE/EPSCOR subcommittee was established to formulate methods and yrinciples of awarding the traineeships, to oversee implementation of the awards, to assess needs and opportunities within the EPSCOR program, and to assist in the development of a successful manpower, education and science and engineering program in energy related research within the commonwealth of Kentucky. Whis subcommittee, reporting to the Kentucky EPSCOR Committee, through the Kentucky EPSCOR Project Director, was part of the overall management structure shown in Figure 1. The DOE/EPSCOR subcommittee consists of people having expertise in energy and energy-related research and development (See Appendix I). Resumes of the chairs of the Kentucky EPSCOR Committee, Kentlicky EPSCOR Project Director and DOE/EPSCOR Subcommittee are given in Appendix II. Recently, the management structure has been amended to include the kentucky science and Technology Council (KSTC); this change and its implications for the DOE/EPSCOR program are discussed below in section $C$. 


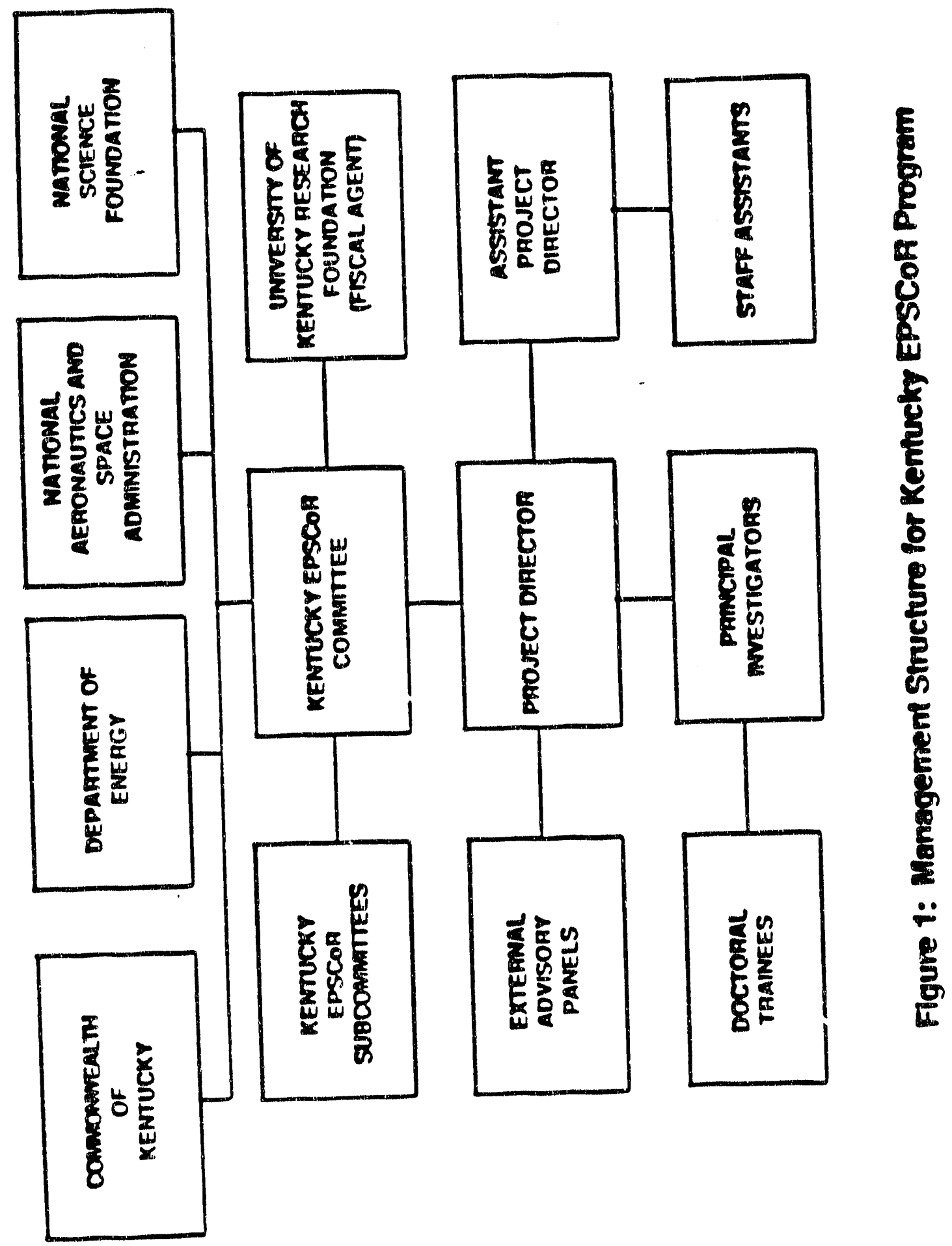


The subcommittee established a competitive process to attract the highest quality stduents and research proposals within the four topical ares of clean Uses of fossil Fuels. The student requirements included:

1. United states citizenship or permanent residence status;

2. Admission into one of the two PhD granting institutions in the commonwealth of Kentucky - i.e. University of Kentucky or University of Louisville; and

3. Commitment to a research plan in ore of the four topic areas.

On October 29, 1991, a "clean Uses of Fossil Fuels" flyer (see Appendix III), announcing in general terms the availability and deadines for the rraineeships, in addition to guidelines and application forms (see Appendix III) were sent to the 26 four-year, public and independent universities and colleges witinin the commonwealth of Kentucky. Of these schools, only the University of Kentucky and the University of Louisville have PhD programs in science and engineering. A letter was also sent requesting that deans, department heads and faculty at these schools inform faculty and potential science and engineering graduate students of the availability of the Traineeships.

To ensure that awarding of traineeships would be a dynamic process during each year of successful funding of the proposed five year Traineeship program, the ten doctoral students to receive awards were categorized as either new or continuing students. The new category included students who had enrolled or would enroll into graduate school for studies and research directed toward a PhD during or after the Fall 1991 semester. The continuing category included students who were well into their dissertation projects. 
The latter category represented either students with approximately one year remaining before completing their dissertation or students who were in the midst of their PhD study and research program. As discussed below, five new and five continuing students were awarded Traineeships.

The deadine for applications for the continuing category of Traineeships was December 2, 1991 and the deadine for applications for the new category of Traineeships was February 27, 1992. This schedule was designed to enable implementation of awards in a timely manner for continuing students and to enable faculty and departments sufficient time for recruiting new students.

Besides the requirement that the research proposal fit into the four topical areas of fossil energy, it was explicitly stated in the announcements for these Traineeships that the success of the applications was dependent on the following aspects of the student and faculty mentor:

2. Extraordinary academic history of the student;

2. A well-planned description of existing or proposed research for continuing students or a well-planned educational program for new students.

3. Strong linkages in the research plan to one of the USDOE multiprogram laboratories.

It was also noted that the awards would be for one year, with follow-on years contingent upon the availability of USDOE funding and demonstrated progress in the student research. The academic credentials required of the students included an excellent grade point average (GPA) and high average score (>1200) on two of the three areas in the general part of the Graduate Record Examination (GRE) . 
Twenty proposals were submitted for the continuing student category and ten proposals were submitted for the new student category. Proposals in the continuing category were written by the doctoral student with discussion and approval of their faculty mentor. Proposals for the new category of awards were written by the faculty because, in this case, most students were not expected to inave progressed to the point of being well versed in possible research or had not yet been admitted into the graduate program.

A proposal review panel, consisting of those members listed in Appendix IV, was convened after the proposals had been prereviewed by panel members. Awards were announced in the continuing student category on December 21, 1991; awards were announced in the new student category on February $28,1992$.

This panel recommended that the ten Traineeships be divided equaliy between the new and continuing student categories. Their recommendation was based on a clearly defined and promising research description and its association with fossil fuels research, the students' academic credentials, and the faculty mentors' research and educational records.

2. Identification and Summaries of Traineeship Research Areas

Thirty proposals were submitted. Not all of the topi $\Rightarrow$ ? research areas originally identified were represented in these proposals. The three that were covered included: a) Carbon Based Materials; b) Catalysis; and c) Environmental Impact and Bioremediation. No proposals were received in the toplcal area of climate Modeling. Upon discussions with faculty involved it this important area of research, it was determined that the reason for 
this absence was associated with the strict twe schedules and the inability to identify doctoral students who met the us citizen or permanent resident status. However, it was also determined that there was significant interest in maintaining this topical area for future competition.

The division of the 30 proposals into the topical areas could be represented by: a) Carbon Based Materials - 13 proposals; b) Catalysis - 5 proposals; and c) Environmental Impact and Bioremediation - 12 proposals. In addition, a number of the proposals crossed topical area boundaries, 1.e. two proposals could be identified as carbon based materials with a focus on environmental impact, two proposals could be ldentified as carbon based materials with a focus on catalysis, and one proposal could be identified as catalysis with a focus on environmental impact.

The quality of the students was measured in terms of their Graduate Record Exam (GRE) scores and cumulative Grade Point Average (GPA - 4.0 representing A). overall, the average GPA of the students was 3.4. The average of their GRE was: 519 - verbal, 654 - Quantitative, and 613 - Analytic. The national mean average of the GRE is: 486 - Verbal, 560 - Quantitative, and 532 Analytic. Hence, the standards set for student quality, i.e. an excellent GPA and a high average score $(>1200)$ on two of the three areas in the general part of the GRE, were met.

Ten out of the 30 proposals submitted were accepted for Traineeship awards. A listing of the students, faculty, their discipline and university, and research title are presented in Table 1. Two of the research projects are on carbon based materials, three are on catalysis of fuels, two are on catalysis 
with environmental focus, and three are on environmental and bioremediation.

Abbreviated resumes of the facilty directing the trainee research are presented in Appendix $v$. $A$ brief abstract of the research to be performed for each of the ten Traineeships are presented on the following pages.

continuing student Traineeships

1) STM Studies of Iron-Manganese Thin Film Catalysts

Student: George Matthew

Faculty: Dr. Kwok-Wai Ng

Physics, University of Kentucky

surface science experiments have shown that metallic ixon is catalytically active but is very susceptible to poisoning by carbon and sulfur deposition. This poisoning is critical to the application of Fe catalysts for Fischer Tropsch (FT) catalysis when using coal derived synthesis gas. competition between hydrogenation of the active carbon and its decomposition into surface graphite along with sulphide (formation) determines the catalyst lifetime. The presence of manganese makes iron catalysts more resistant to such poisoning.

Matthew and $\mathrm{Ng}$ plan to study, by use of scanning tunneling microscopy (STM), the surface of the various composition films of iron and manganese in controlled atmospheres of hydrogen, carbon- 

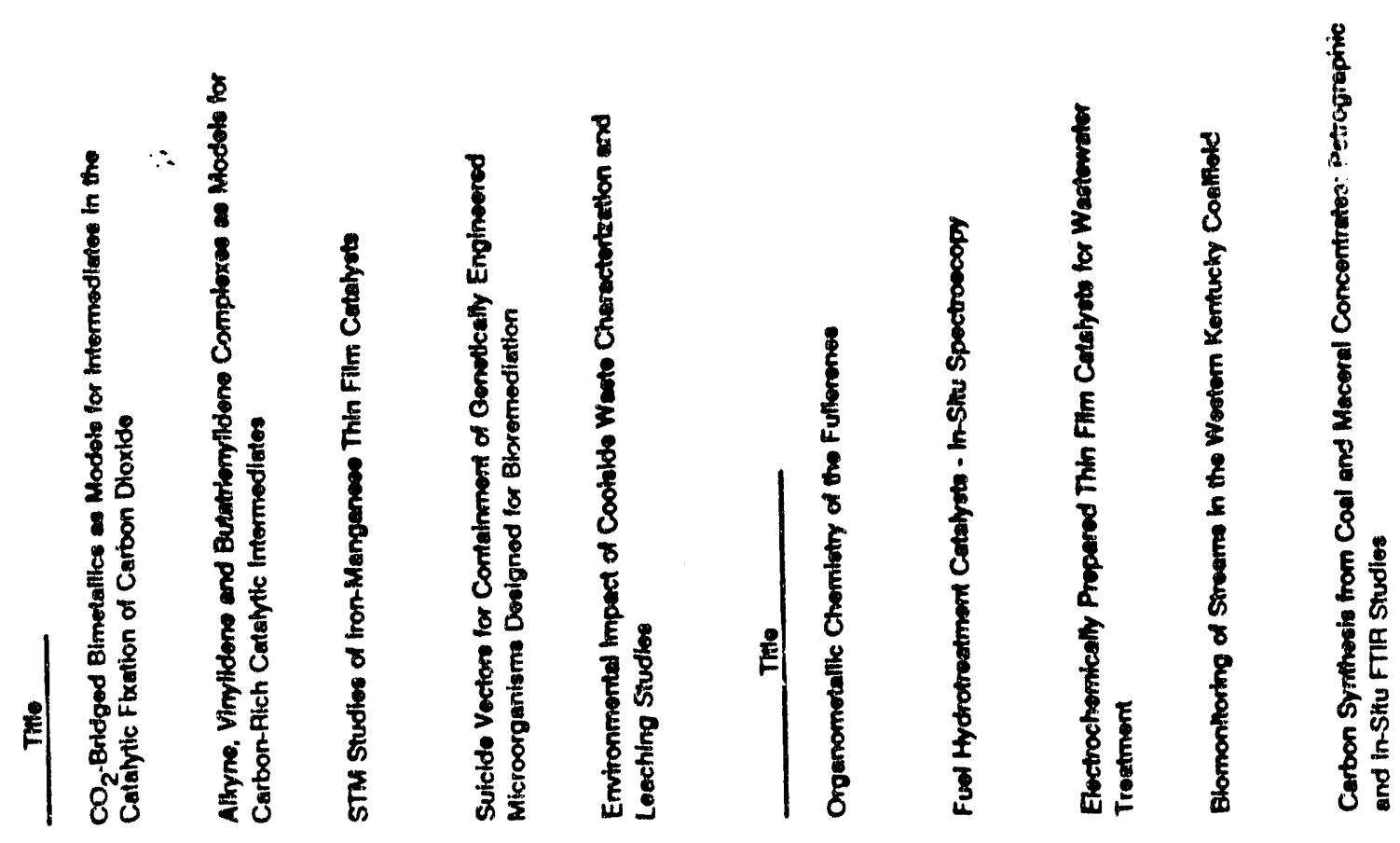

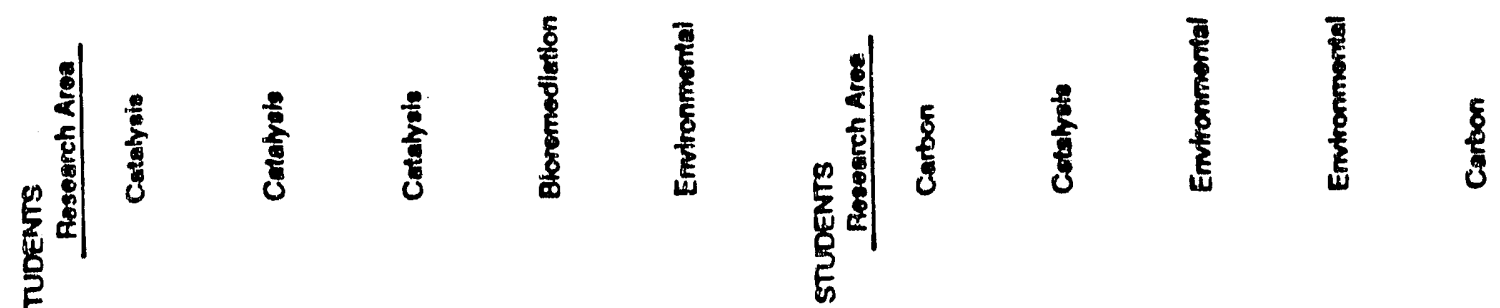

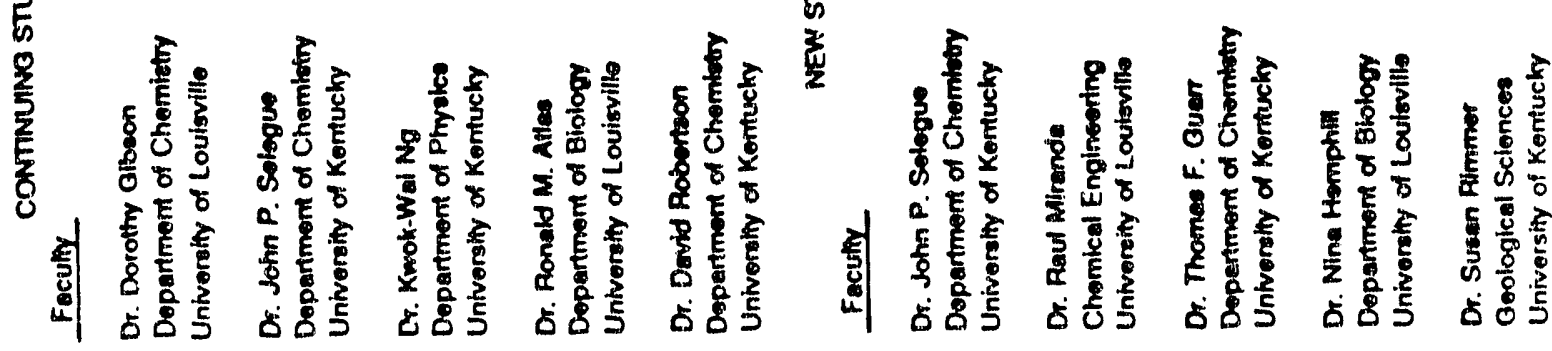
$\frac{\text { 焉 }}{\frac{0}{\frac{0}{5}}}$ . 
monoxide and hydrogen ulphlde. Since sTM has atomic resolution capabilities, the research w112 focus on 1dentifyling the location of sulphur poisoning and the role of kn in providing sulfur tolerance. Surface changes of the fims resulting from carbon deposition, and possibly graphite formation, will also be examined. No one so far has been able to determine the true threvdimensional graphitic structure formed under these conditions.

2) Alkyne, Vinylidene and Butatrienylidene Complexes as Models

$$
\begin{aligned}
& \text { student: Jeffrey R. Lomprey } \\
& \text { Facilty: Dr. John P. Selegue } \\
& \text { Chemigty, University of Kentucky }
\end{aligned}
$$

The research will involve the etudy of carbon-rich, organometallic compounds wich model proposed intermediates in Fischer-tropsch synthesis of alcohols and hydrocarbons and in acetylene conversion. The goal of the research is to prepare and isolate molecules that are similar to those which are present in the conversion pathway of carbon monoxide and hydrogen mixtures to various, useable fuels. This research will provide a better understanding of the chemical reactions which govern many of the industrial processes that are used to produce the fuels we use each day.

The types of compounds which are of interest are those containing carbide, vinylidene $\left(: C \mathrm{CR}_{2}\right)$, butatrienylidene (:CuC=C=CR ), and other cumblene fragwents. These compounds are highly reactive and do not exist by themselves as stabie entities. Therefore, stabilization will include fragment binding to various complex fragments of those metals that are usulily present in the Fischer-orropsch cacalysts. 
Eforts to gynthesize mononuclear butatrienylidene complexes in the past have met with no success. Lomprey and selegue, however, have lsolated the first transition metal complex containing a butatrienylidene 11gand, which has been ablablized by bonding to a trifluoroacetate group. Continuing studies, as well as the syrichesis of other complexes containing different anciliary ligands and substituents on $C_{6}$, are to performed within this project.

3) $\mathrm{CO}_{2}$-Bridged Bimetallics as Models for Intermediates in the Catalytic Fixation of Carbon rioxide

Student: Michael T. Marris

Faculty: Dr. Dorothy H. Gibson

Chemistry, University of Louisvilie

Two xajor energy-related problems that face the United States today are the finite nature of world petroleum reserves and the greenhouse effect caused by excess emissions of carbon dioxide into the atmosphere. Both problems could be minimized if a costeffective method for the conversion of carbon dioxide into organic chemicals traditionally derived from petroleum could be developed. Carbon dioxide alone represents cheap and abundant source for these organic chemicals. However, a major problem with the use of carbon dioxide is that a large energy input is required for activation; this energy input can be reduced by the use of metal catalysts.

The emphasis of Harris and Gibson's research is on the preparation of compounds which are models for catalytic intermediates involved in the activation of $\mathrm{CO}_{2}$. These compounds will involve bifunctional coordinaticn utilizing a very basic metal center to bind the $\mathrm{CO}_{2}$ carbon and an acidic metal to bind the 
oxygens. It will focus on bimetalilc compounds of the late transition metals which have a $\mathrm{CO}_{2}$-contalning bridge.

compounds linking a metallocarboxylate anion with an ethylenecoordinated anion will be studied initially. Fyarogenation reactions which may remove the carboxyethylene bridging group as ethyl formate, a useful raw material for chemical industry, shall also be attempted. Efforts will be made to extend the linking procedures to include reactions between metallocarborylate anions and dienes or alkynes and to compare the reaction characteristics of these to the carboxyethylene-bridged compounds.

4) Suicide Vectors for containment of Genetically Engineered Microorganisms Designed for Bioremediation

Student: Adam L. Stell

Faculty: Dr. Ronald M. Atlas

Biology, University of Loulsvilie

A crucial environmental concern is the control and elimination of hazardous materials that have contaminated the soil, air and water. Many of Lhese contaminant "xenobiotics" are a direct result of the use, processing, and disposal of fossil fuels and by products such as anthracene, benzopyrene, fluranthrene, phenolics, as well as thiophenes, dibenzothiophenes, and phenyl sulfides (found in coal).

Recently, bioremediation has been suggested as a possible solution to solve many contamination problems associated with fossil fuels. However, the idea of using genetically engineered microbes (GEMS) to solve iuch problems has raised concerns as result of the lack of knowledge regarding the fate and effect of GEMs released into the environment. once released, there is no 
method for recalling GEMs, and no way of controlling their growth, spread, or interaction with the environment.

The goal of the proposed research 18 to develop eystems for reducing risks associated with the deliberate environmental release of GEMs. Prototype containment systems for GEMs are to be examined.- These systems will include the polymerase chain reaction to amplify promoters and structural genes that can be coupled as suicide vectors for the containment of pesticide and toxic chemical degrading microorganisms. For example, a GEM that contains a built-in self-destruct mechanism would only survive long enough to complete its task, and then would eliminate itself from the environment it was released into. Such a mechanism would involve the use of environmental cues, such as the absence of the contaminant, to lead to the destruction of the GEMs. This system could theoretically be used with any GEM, including those being engineered for degrading fossil fuel xenobiotics. It should be possible to design a conditional lethal system such that the lethal system is "on" once the GEM has degraded the xenobiotic. Thus, the GEM which contained this "suicide vector" would only survive under the specific environmental conditions of its intended use.

5) Environmental Impact of Coolside waste Characterization and Leaching studies

\section{Student: Amy wong}

Faculty: Dr. David Robertson

Chemistry, University of Kentucky

Coolside is a dry flue gas desulfurization process for removal of $\mathrm{SO}_{2}$ from coal fired power plant emissions. The technolngy was successfully demonstrated at the Ohio Edison Edgewater Plant under the DOE Clean Coal Demonstration Program. However, before the 
coolside process can be employed commercially, the environmental impact of the disposal of coolside waste must be assessed. The wastes differ from other ary scrubber wastes in that the residual Iime remains partially hydrated and from other low temperature scrubbing wastes in that the sorbent activator will introduce significant quantities of sodium compounds in the waste.

The research will study both the chemical composition and field and laboratory leaching properties of the coolside solid waste. About 400 samples will be analyzed for the major, minor, and trace elements by two ion beam analysis (IBA) techriques: particle-induced $X$-ráy emission (PIXE) and particle-induced gammray emission (PIGE). By combining these two techniques, all elements (except $\mathrm{Hg}$ ) of major and minor concerns can be readily determined in a single irradiation.

The data from the Coolside solid waste and leaching studies will be evaluated by geschemical computer models, such as GEOCHEM and WATEQ, to determine the solution-equilibrium phenomena operative in controlling the leaching chemistry. This chemical information will be utilized to determine if there are any chronic or acute elemental release problems from the waste and the possible effects on the environment.

\section{New Students Traineeships}

6) Organometalidc Chemistry of the Fullerenes Student: Thomas Allison

Faculty: Dr. John P. Selegue Chernistry, University of Kentucky

Fullerenes are closed, polyhedral clusters of carbon atoms, the best known of which are soccer-ball-shaped $c_{60}$ and egg-shaped 
$\mathrm{C}_{70}$. These molecules were first generated in minute quantities by the laser ablation of graphite, and detected by using mass spectrometry. In 1990, Kratschmer, Huffmann añd coworkers discovered that gram quantities of fullerenes could be extracted from the soot produced by discharging graphite electrodes in a lowpressure helium atmosphere. It is relevant to the DOE mission of studying carbonaceous materials that fullerenes can be prepared directly from contact-arc evaporation of coal-derived coke, as well as chromatographically separated on previously extracted coal powder.

Much of the excitement about fullerenes and derivatives is because of their physical properties in the solid state. Their transition metal complexes are soluble models for catalysts consisting of active metals deposited on graphite or other absorbent carbons. These organometallic model compounds should provide significant information about the structures and reactivity of catalytically relevant metal carbide species.

Allison and selegue propose to add $\mathrm{CCl}_{2}$, readily derived from thermolysis of $\mathrm{PhHgCCl}_{2} \mathrm{Br}$ or various other sources, to fullerenes. The product of one addition would be $\mathrm{C}_{61} \mathrm{Cl}_{2}$; if $\mathrm{CCl}_{2}$ addition is successful, displacement of chloride by organic nucleophiles $R^{\text {. }}$ could lead to a host of organic fullerene derivatives $C_{6} R C I$. Redox reactions of chlorofullerenes derived from $c_{60}$ or $c_{70}$ could provide a pathway to the predicted "magic number" fullerides $\left(C_{n}^{2-}, n=74\right.$, 82, etc.) and fullerenium ions. In addition, the addition of $\mathrm{GeCl}_{2}$ (dioxane) to $\mathrm{C}_{60}$ would lead to $\mathrm{C}_{60} \mathrm{GeCl}_{2}$, the first germafullerene. 
Although certain of the fulleride anions have been isolated as pure salts, it may be more convenient to carry out these reactions simply by adding the requisite amount of an alkali metal to a mixture of a fullerene and a metallocene, without actual 1solation of the fulleride anion. A more ambitious, but exciting, ldea is to displace both cyclopentadienyl ligands from a metallocene, forming a pure metal-fullerene complex. Allison and selegue propose to search for hydrometallated fullerenes. In a preliminary study, selegue found that $C_{60}$ reacts with schwarz reagent under mild conditions, giving a solid product which he is attempting to characterize.

7) Carbon synthesis From $\mathrm{Coal}$ and Maceral Concentrates: petrographic and In-Situ FTIR studies

\section{Student: Christopher A. Toles}

Faculty: Dr. Susan M. Rimmer Geological Sciences, University of Kentucky

Activated carbons are used extensively in diverse applications: potable and waste water treatment; respirators; solvent recovery from process streams; air and gas purification; reducing gasoline vapor emissions from automobiles. More specialized uses, sometimes involving the addition of impregnants, are in catalysis, medicine, military gas masks and gold recovery.

The proposed research addresses the conversion of coals to adsorbent carbon. The focus will be on the role played by different maceral groups in thermal and chemical synthesis processes. The specific objectives of the proposed research are to study the transformation of subbituminous coal to porous carbon through thermal and chemical activation (using phosphoric acid), emphasizing the alteration of different maceral groups and the role 
these components play in the development of porosity; to develop a basic understanding of reaction chemistry and mechanisms involved, how they relate to precursor structures, and how they relate to structural changes which lead to the development of high surface areas.

8) Fuei" Hydrotreatment catalysts - In-situ spectroscopy

Student: James H. McNeill

Faculty: Dr. Raul Miranda

Chemical Engineering, University of Louisville

clean-up of sulfur and nitrogen heterocyclic aromatics from

heavy liquid fuels can be achieved via the process of hydrotreatment (HDS, HDN), which takes place in catalytic reactors at high pressure of hydrugen (100 atm) and temperature (ca. $700 \mathrm{~K})$. The main goal in the development of catalysts for this process is to attain high activity and selectivity towards desulfurization and denitrogenation. Such activity for denitrogenation of heavy oils is too low in current catalysts, which were developed for desulfurization of light oils. An improvement is likely to occur with an increased understanding of the electronic and geometric structure of selective sites, and of the mechanism of hydrodenitrogenation.

In this project, current knowledge about the geometry of selective sites on supported Mo sulfide catalysts will be supplemented with infornation about the electronic environment of such sites. This task will be accomplished via the use of positron annihilation spectroscopy, a technique that is being developed for catalytic applications in our laboratory. An important difference between electron spectroscopies (e.g. EEIS or XPS) and positron spectroscopy is that the latter can be applied during actual 
reaction, providing electronic information of the catalytic site under working conditions. The results of this investigation will produce advances in both fundamental catalysis and applied spectroscopy.

9) Electrochemically Prepared Thin Film Catalysts for wastewater Treatment

Student: Lynda R. Rupp

Faculty: Dr. Thomas F. Guarr

Chemistry, University of Kentucky

A wide variety of methods have been employed for the removal of impurities from water, fuels, and flue gases, including the air oxidation of the most prevalent sulfur contaminants. Among the more active catalysts in many such processes are macrocyclic complexes of transition metals. Much of the work involving the removal of sulfur-bearing contaminants (primarily from wastewater) with metallomacrocycle catalysts has taken place in the soviet union, and is directed toward the recovery of sulfur in a two-stage process, using a minimum of oxygen.

polymeric catalysts (ox catalysts incorporated in polymer matrices) have not been extensively investigated as redox catalysts, despite the fact that such materials offer a number of distinct advantages. First, polymer systems generally display increased catalytic activity as compared to the monomeric species. second, turnover numbers are improved, often by a factor of $10^{2}$ or more. Finally, the control of polymer morphology can lead to increased catalytic selectivity and/or resistance to fouling.

Guarr has recently discovered a simple method of altering film morphology from a smooth impermeable layer to a microporous structure more suitable to catalytic applications. In general, carbon substrates, including high surface area materials, will be 
employed, although the electrodeposition of metal layers either prior to or following the polymerization process will also be explored. This approach takes advantage of well-established electrochemical technlgues such as chronocoulometry and linear sweep (or cyclic) voltammetry for the rapid and quantitative evaluation of catalytic systems. More importantly, these methods will yield fundamental mechanistic and kinetic information which will serve to guide future catalyst development.

Initial efforts will target porphyrins and related ring systems such as phthalccyanines and tetraazannulenes as potential catalysts. We will focus primarily on the development of polymeric catalysts for the oxidation of aqueous sulfides, thiols, and mercaptans. In addition, the activity toward other thermodynamically accessible processes such as the oxidation of aromatic acids, amines, and hydrazines will be tested.

10) Biomonitoring of streams in the Western Kentucky coal Field Student: Jennifer slate Faculty: Dr. Nina Hemphill Biology, University of Louisville

Many streams in the commonwealth of Kentucky are affected by mining and reclamation activities associated with coal production. Nearly 170 million tons of coal are produced per year in kentucky, with production distributed between its eastein and western coalfields. These mining efforts include surface and underground operations. In western Kentucky, over 558 of the approximate 48 million tons of coal produced is from surface mines.

In the Green and Tradewater drainage systems in western Kentucky, many streams are severely impacted by mine drainage from coal mines. Surface mine drainage is highly acidic and contains 
high levels of heavy metal contaminants. The adverse impacts on streams can last for years after the closure of a mining operation. The proposed research is in assessing: 1) the current impacts of acidification and heavy metal contamination on stream communities; and 2 ) the success of bioremediation in enhancing the recovery of impacted stream communities. Biomonitoring, gauging the health of aquatic ecosystems, and assessing impacts of perturbations such as mine drainage on fish and aquatic invertebrates will be investigated.

Besides formal coursework in advanced statistics, and ecosystem, mathematical, Invertebrate, stream and community ecology and the research in the Green and Tradewatier drainage basins, Ms. slate will work with Drs. A. Stewart (Ecotoxicology) and J. Loar (Fisheries) at Oak Ridge National Laboratories during the summer of 1993.

3. Practicum Arrangements and Plans

The cald for proposals from the DOE/EPSCOR subcommittee involved a strong recommendation that provisions for a practicum at a USDOE or affiliated laboratory be arranged. However, a practicum was not a prerequisite for funding. Rather, the quality of the proposed research and student/faculty team within the topical areas of interest were considered the most important elements for awarding Traineeships. During the next funding period, as outlined in section $c$ relating to practicum programs available within oak Ridge Associated Universities, the Kentucky EPSCOR Committee and the DOE/EPSCOR Subcommittee will discuss revisions of the practicum 
recommendation relative to ssisting faculty and tudents develop interactions with DOE laboratories.

currently, four faculty have arranged practicum experience for the students at DOE multiprogram laboratorles. For example, chris Toles (Dr. S. Rimmer, Mentor Faculty) will spend time during one or more summers at Los Alamos National Laboratory with Dr. Robert Raymond and Dr. Don Hickmott. The exact detalls and dates have yet to be arranged.

During the summer of 1993, Jennifer Slate (Dr. N. Hemphill, Mentor Faculty) will work with researchers at Oak Ridge National Laboratories. She will report to Dr. A. Stewart (Group Leader for Ecotoxicology) and Dr. J. Loar (Group Leader for Fisheries). She can also work on biological monitoring projects overseen by Dr. Loar ( $f i s h$ ) or Jon Smith (aquatic invertebrates).

Interactions with DOE-supported investigators has occurred and will continue for Michael T. Harris (Dr. D. Gibson, Mentor Faculty). Preliminary work has been presented at the 3rd DOE/Basic Energy sciences conference on organowetallic chemistry and Homogeneous Catalysis in June, 1991 at the University of Wisconsin, Madison.

one of the researci topics of Jeffrey Lomprey is the inverconversion of $\eta^{2}$ alkyne and vinylidene ligands on transition metal centers. R. Morris Bullock at Brookhaven National Laboratory also has an active research program in the area, having published the first alkyne to vinylidene conversion which could be followed kinetically. Dr. Bullock would be very willing to host a visit by Mr. Lomprey to carry out collaborative work in this area; a visit in summer 1992 looks feasible. 


\section{B. Current Problems or Unusual Developments}

The Kentucky DOE/EPSCOR Traineeships in Clean Uses of Fossil Fuels were divided between new and continuing student categories to enable a continual and dynamic flow of doctoral students through the program. Relative to the new student category, a topic of most concern was related to the critical issue of timing for recrultment of outstanding students who had not confirmed their attendance to graduate school in the fall of 1992. This potential problem was resolved by an early notification (March 2) to faculty who had submitted proposals. Hence, if faculty had identified outstanding students for the Traineeships and if the students had expressed interest in the research area but had not obligated themselves to attend either the University of Kentucky or the University of Louisvilie, the availability of the prestigeous Traineeship enhanced the recruitment of the student. Associated with this relatively early awarding date was the decision that the award was contingent on not only the proposed student/faculty team but also on the quality and area of the proposed research. If the new student wid not accept the Traineeship, a new and outstanding student would be recruited by the faculty mentor and approved by the DOE/EPSCOR subcomittee to fulfill the needs of the proposed research.

c. Summary of Effort in succeeding Funding Period

The effort in the succeeding funding period will be similar to that described in section $A$. New aspects, as describe below, will also be added to enhance the quality and diversity of students and research disciplines anc the participation in the practicum experience. 
First, an effort will be made to promote and increase the participation of students in practicums at a USDOE multiprogram laboratories. This aspect has been discussed with Dr. Richard Weisehuegel, Program Director at Oak Ridge Associated Universities (ORAU). The effort will entail interfacing the DOE/EPSCOR Traineeship program with a DOE program administered by ORAU, for example, the Graduate student Research Participation program (GRSP) and/or the Travel/contracts.

Within the GRSP, a contact person at a DOE or affiliated laboratory requests in cooperation with a university faculty advisor and through Dr. Weiseheugel's office at ORAU that a graduate student be approved for a research visit at the requestors facility. Normally, a GRS award is a one time appointment for a period of one-to-twelve months during which time the DOE/ORAU pays the student a stipend, plus travel to-and-from the racility. within the proposed Interfacing, the student's DOE/EPSCOR Traineeship would pay the students stipend whereas the GRSP would pay for travel to and from the DOE multiprogram laboratory. Hence, the proposed interfacing would extend the number of interactions possible within funding that is available for GRSP and, simultaneously, enhance the quality and patticipation in the DOE/EPSCOR Trainseeships.

Another interfacing that will be promoted is within the ORAU Travel/Contracts. This program, like the GRSP, would be dependent on the research cooperation between personnel at a DOE multiprogram laboratory and the USDOE/EPSCOR faculty and student trainee. Travel contracts are for a maximum of ten days pex visit with the ORAU normally paying costs for transportation, hotel and a per 
diem. The utjilzation of these travel grants by both faculty and students would greatly enhance their research experience and outlook on 1ssuer of national importance.

The last aspect of interfacing with ORAU is the possibility of using the research contacts that are avallable through $D r$. weisehuegè's office. such contacts could be as simple as a list of expertise and location of personnel at DOE or national laboratories that perform research in topical areas similar to those awarded in the Traineeships. In addition, Dr. Weiseheugel has offered to assist in arranging research participation of the graduate students at laboratories other than those covered by his ORAU office. For example, research participation at Argonne National Laboratories is not administered through ORAU but the proper channel through which participation should be directed is known by him. such assistance would benefit the rraineeship program and provide positive links to research programs otherwise not known to exist or difficult to locate.

The participation of graduate students and faculty in industrially relevant research is as important as the practicum experience that can be gained at usDOE facilities. In fact, the USDOE mission is closely tied to the energy industry within the united states. To enhance ties with energy industry and to promote research that could assist the investigation of new and cutting edge technologies that industry could use or develop, the kentucky EPSCOR Comittee has signed a Memoranaum of Agreement (MOA) with the Kentucky science and Technology council (KSTC) (see Appendix VI). 
The KSTC was formed in 2987 for the purpose of promoting science and technology development in Kentucky. Although six members of the Kentucky EPSCOR Committee are nember of the KSTC, Including Dr. Lee $r$. Todd, Jr. (President of Databeam Corporation and a former UK faculty member) who serves as chalrperson of both organizations, only recently has there been established a formal link between the two organizations. As a result of this MOA, it is expected that, working togethor, the iwo organizations will be able to provide strategic deadership, better coordination of programs and more efficient utilization of resources in the promotion of science, technology and innovative economic development in Kentucky. Additionally, the creation of a single entity should enable the development and implementation of comprehensive statewide programs, policies and services in education, scientific research and economic development.

With respect to the DOE/EPSCOR Traineeship program, it is envisioned that the MOA will enable an enhanced industrial component to the research that is to be performed. The KSTC has statewide industrial contacts and inftiatives which could be coupled with the overall effort of the Traineeship program. For example, participation by Kentucky energy industries in support of proposed research projects could be promoted through the MOA. This support would extend the benefits of the DOE/EPSCOR program beyond Its funding level and raise the level of manpower development beyond that otherwise anticiputed.

III. BUDGET EXPLANATION

The following pages delineate the budget for the one-year effort. UK and $U$ of $I$ cost-shared $5 t$ of the academic year salary 
or calendax year salary for the KY EPSCOR Project Director, DOE/EFSCOR Subcomittee nembers, Assistant Project Director and a staff Assistant. The universitiles have provided $\$ 3,000$ for travel, meetings, seminar series, and cfice costs. The amount requested per trainee included stipend, tuition, supplies, and travel. The average cost of each traineeship was $\$ 25,000$. costs for out-ofstate tuition were contributed by the universities. Plans for augmenting or supplementing trainee costs from other non-federal sources include obtaining industry support for collaborative projects. A total of $\$ 25,475$ in indirect costs was waived for year one of the Kentucky DOE/EPSCOR Traineeship Program. 
A Coior Prowel

8. W. W.D. Comally, Proper Duraor

- vi.pr Calodir Yer salar

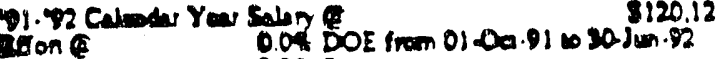

Tron o. Suls

To on 0.04 indusing

Tom

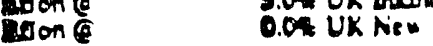

20

$\infty$

20 cusos

20 44.80!

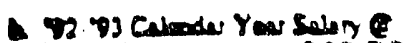

8132.133

acon

Fon

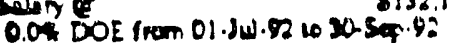

Hor

Efion e

0.09 Sule

0.04 Indurim

Eone

s.oe Lixinting

D.O UR New

Tow

2020

$80 \quad 81,652$

80 s1.6::

808

80.157

$80 \quad 26.157$

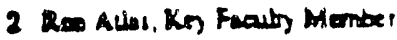

- \$1. Acosonis Year Suler

876.860

Esione

Esion

ETOA

Irion

Esion

O.02 DOE Irom 01-0en.91 wis. Mor.92

o. on suls

Q.0 Indusin

g.0 L L o L linkind

0.04 Li L L Aew

8

20

802.02

80

- 92.03 aodens Year Salon.

$\sec 240$

Etron

Eliong

Esion

Elion

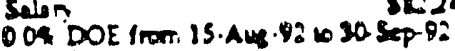

O. On Sinte

o.or indusin

Elone

g.on L' $\alpha L$ inkend

o.or iv a Lnew

Tow

$80 \quad 80$

$\infty$

\$914

80

ssid

20

80

$10 \quad 82.916$

30

s:916

3 Froud Detortire Nes Faculis Membe

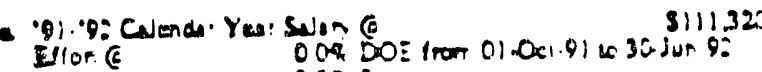

Entos

Elor ck

Ellor ह5

Ellor है

o or sili

o or inessin

sog, ¿N invin

o or lít ber

- 9a 9: Culedar Ten Salon E

Elior ce

Elio-

Eslore

Ellor. (6)

o sur

o or induatra

s oq Liti livina

Ellor é

o On LA Re.

Tou:

$80 \quad 80$

$20 \quad 81.531$

si 3:?

80

80

$80 \quad 85.700$

3: 3: ?0

- Dorah, Gitasc. Ke, Fuall, Membe:

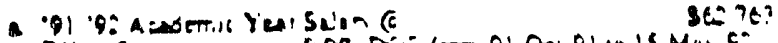

Ello-e

Elice

och Sis

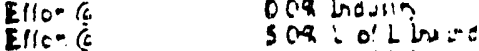

Ellorice ooniolihew

so

so 31.9t:

s: s: $x$

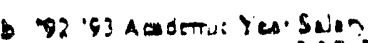
sta.e?

ES10- 6

Effo. (

Eflor ic

ESTor.

Esion. (E

OCA DOI ino Is Aus 9: 2036 Sef 9:

och siste

o or hisurin?

$s 04:$ ol $L$ irs ind

o or i of lite.

Tan'

\begin{tabular}{|c|c|c|c|c|}
\hline so & 30 & 80 & $5+16$ & si \\
\hline$\$$ & 80 & 80 & 2237 & 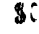 \\
\hline
\end{tabular}




DOE STATE DNDUETRY ENOND UATV TOTAL

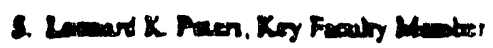

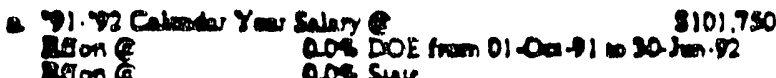
Tom
7 on
Ione Dor UK new

- Y.03 Caboder Yan Salin E

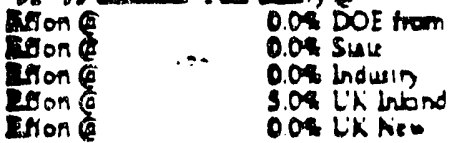

Tow

TOTAL SETTOR PERSONXEL

- Other persomiel

1. Bumon L Price, Asurean Projod Drease

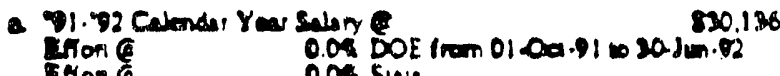

Ehon 0.04 Suls

EMon G 0.04 Indusin.

Elone s.on UR ineuno

Elione o. ON UR tie:

$\begin{array}{llllll}80 & 80 & 80 & 81.130 & 80 & \$ 1.130\end{array}$

- Pr.03 Culendar Year Salas

Sلsing 833.130

80

80

$20 \quad 2816$

$80 \quad 83.816$

Erione

Exton है

Exion

ODA DOE from 01.JW. 92 L0 30.509 .92

Erion a

Q.00R Sule

Ellon

O.con Indurin

D.004 LA Intun

Tou'

$\begin{array}{llllll}80 & 80 & 80 & 81399 & 80 & 81399 \\ 80 & 20 & 80 & 25213 & 80 & 89215 \\ 50 & 80 & 80 & 20371 & 80 & 82371\end{array}$

2 To Be Amex Su" Alusum

- 91.92 Calenda rien. Salan e sitiat

Esien:

Esion

EMon

EMor 6

O Ong DOE 1000 010.1.01 k30 Jun 9:

o Out Suls

ooca indusin

goom liv livine

Elione 0.004 Lid.t.

80

80

80

201

80

84:

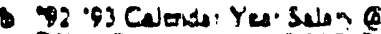

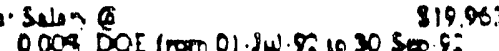

Esion.

Elion E

Efiom

- oce DOE Iram 01.84. 95103054.9

Elion E

oon siove

o con indusin

Elion

soch l'k lineins

$0 \propto 0$ Litis.

Tou'

TOTAL SALARES AND WACES

C FRRICE BEVEFTS

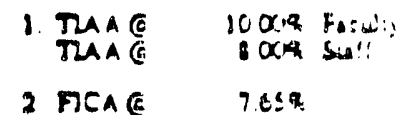

3 Heats Benefin (bx' pesi) e

TOTA: FRACE BEIEFTTS

TOTAL SALAPES WACES AAD FRNDEE BEVEFTS

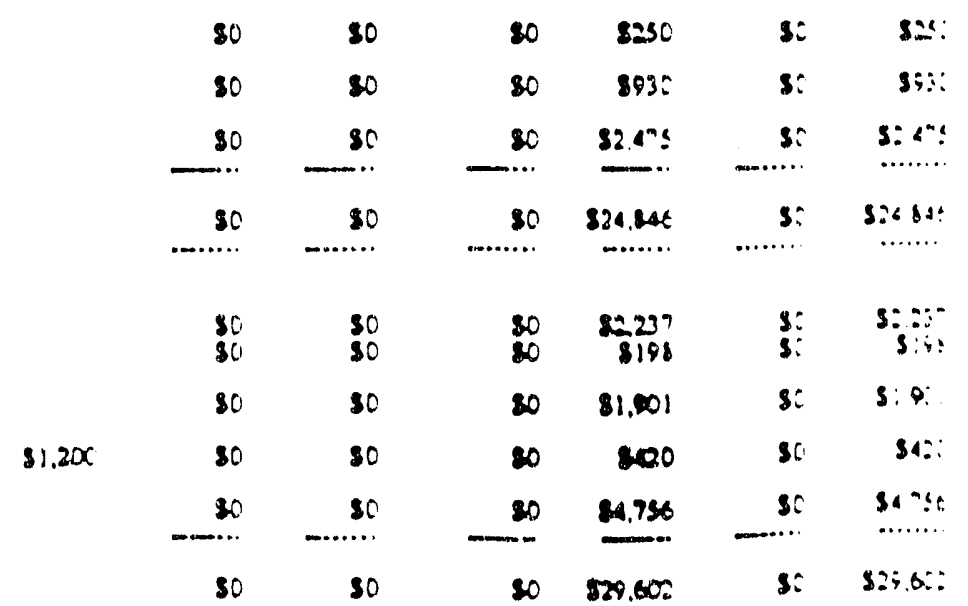


RUVEL

TOTAL TRAVEL

G. OTHDX DRECT COSTS

1. Manals soppla

- Oscor suppilies

a. Odet

- Comomiar Mecars.

- Doconi Tnumeshup'

1. Sapand (10) 6

27 man $(10)$

3. Eppies $(10)$

4. Tow (10)

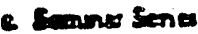

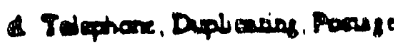

TOTAL OTHER DIRECT COSTS

H TOTAL DTRECT COSTS

2 SWDDRETT COSTS

1. MTOC - Bax lOO DOE

2 are MTDC Bes la Sure

3 ap NTTC . Bux la Indus:"?

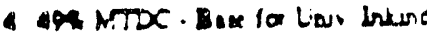

s aph ntoc - Bax fo Lnu Nens

TOTAL DDIRECT COSTS

TOTAL DRECT ALD IDDRETT COSTS

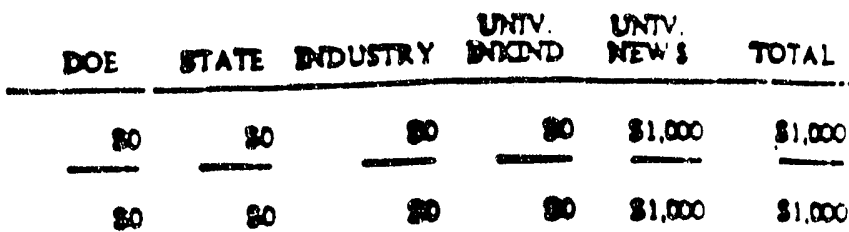

$\$ 18,000$

82,000

83,000

2000

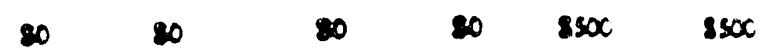

\begin{tabular}{|c|c|c|c|c|c|}
\hline 80 & 80 & 20 & 20 & 8250 & 8230 \\
\hline 10 & 80 & 20 & 80 & 10 & \\
\hline 8120,000 & 80 & 20 & 80 & 80 & $\sin 0, \alpha$ \\
\hline 00,000 & 80 & 80 & 80 & 80 & 82 \\
\hline 80000 & 20 & 20 & 80 & 20 & $8 x$ \\
\hline 20000 & 10 & 20 & 8 & 80 & \\
\hline 80 & 80 & 80 & 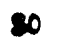 & 81.000 & \\
\hline$\varepsilon$ & 80 & 80 & 8 & 2250 & \\
\hline
\end{tabular}

\begin{tabular}{|c|c|c|c|c|}
\hline 8250.000 & 80 & 80 & $\infty$ & 22.00 \\
\hline 10 & 8 & 80 & 20,602 & 83,000 \\
\hline
\end{tabular}

\begin{tabular}{|c|c|c|c|c|c|}
\hline 80 & 80 & 10 & 20 & 80 & $s$ \\
\hline 30 & 80 & 10 & 80 & 80 & 80 \\
\hline 80 & 80 & 30 & 20 & 80 & 3: \\
\hline $8 x, 65$ & 80 & 80 & 80 & 814so! & se \\
\hline 83.000 & 80 & $\infty$ & 80 & 81.770 & $\$ C$ \\
\hline & 10 & 20 & 20 & 815.979 & 30 \\
\hline & & 20 & 10 & $4 \leq 577$ & $83.0 x$ \\
\hline
\end{tabular}




\section{APPENDIX I \\ MEK- 'RB OF KY EPBCOR COMAYTTEE AND \\ DOE/EPBCOR BUBCOMAITTEE}




\author{
Chair: Dr. Lee T. Todd, Jr. \\ President \\ DataBeam Corporation \\ 3256 Lochness Drive \\ Lexington, KY 40517
}

Dr. Gary $\hat{\text { w. Boggess }}$

Dean of Science

Blackburn 261

Murray State University

Murray, KY 42071

Mr. Ronald J. Carson

Deputy Diretor

Office for Policy and Management

Roox 201, Capitol Annex

Frankfort, KY 40601

Dr. Virginia P. Falkenberg

Dean, Graduate Studies Research

Graduate School

Coates Box 5A

Eastern Kentucky University

Richmond, KY 40475

Dr. Patrick Flanagan

Vice President for Research

and Dean of Graduate school

University of Louisville

Louisville, KY 40292

Dr. William P. Hettinger, Jr.

147 Deer Creek Blvd., Apt.407

Hidden Woods

Deerfield Beach, FL 33442

Mr. Kris Kimel

Executive Director

Kentucky science and Technology

Council

First National Building

167 W. Main St., Suite 906

Lexington, KY 40507
Dr. Charles E. Kupchella, Dean Ogden college of science, Technology and Health

Western Kentucky University

Bowling Green, KY 42101

Dr. Lee J. Magid

Vice President for Research and Graduate studies

University of Kentucky

207 Administration Building

Lexington, KY 40506-0032

Dr. Barbara McLaughlin

Opthalmology and Visual Sciences

University of Louisvilie

Louisville, KY 40292

Dr. Wimberly C. Royster

Special Asst. to the President

University of Kentucky

$514 \mathrm{H}$ Robotics Building

Lexington, KY 40506-0108

Ms. Judi L. Streepey

IBM Account Executive

Commonwealth of Kentucky

P.O. Box 12628

Lexington, KX 40583

Dr. James $H$. Wells

Mathematics

University of Kentucky

735 Patterson office Tower

Lexington, KY 40506-0027 


\author{
Chair: Dr. John stencel \\ Associate Director \\ Center for Applied Energy Research \\ University of Kentucky \\ 3572 Ironworks Pike \\ Lexington, KY 40511-8433
}

Dr. Frank J. Derbyshire, Director Center for Applied Energy Research and Professor of Chemical Engineering

University of Kentucky

3572 Ironworks Pike

Lexington, KY $40511-8433$

Dr. Thomas R. Hanley, Dean

speed scientific school

University of Louisville

Louisville, KY 40292

Dr. Lee J. Magid, Vice President

Research and Graduate studies University of Kentucky

207 Administration Building

Lexington, KY 40506-0032

Dr. Marc T. McEllistrem

Professor of Physics and Astronomy University of Kentucky

177 Chemistry-Physics Building

Lexington, KY 40506-0055
Dr, John T. Riley, Director

Center for coal science and Professor of Chemistry western Kentucky University Thompson Complex-North Wing Bowling Green, KY 42101

Dr. Wimberly C. Royster Special Assistant to the President. University of Kentucky 514H Robotics Building Lexington, KY 40506-0108

Dr. Joseph M. Steffen Professor of Biology 210 Life sciences Bldg. University of Louisvilie Louisville, KY $\$ 0292$ 


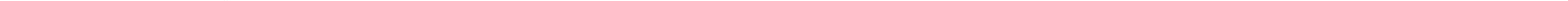




\section{A. Cheir, rBTC and rentucky EPBCOR comitten}

Name:

Lee T. Todd, $J x$.

Institution: DataBeam Corporation

Address:

3256 Lochness Drive Iexington, KY 40503

Telephone:

(606) 273-3204

S.S. Number:
Projectron, Inc.

$404-56-4641$

Projectron, Inc.
200 Big Run Road

Lexington, KY 40503

(606) 278-5002

\section{EDOCATIONAL BACKGROOND}

$\begin{array}{ll}\text { Ph.D. } & \text { Electrical Engineering, MIT, } 1973 \\ \text { M.S. } & \text { Electrical Engineering, MIT, } 1971 \\ \text { B.S. } & \text { Electrical Engineering, UK, } 1968\end{array}$

\section{PROFES8IONAX EIPERIENCE}

Dr. Lee T. Todd, Jr. is the President and founder of two Lexington, Kentucky-based high technology firms, DataBeam corporation and Projectron, Inc.

DataBeam Corporation manufactures teleconferencing systems which use very high resolution displays. The DataBeam CT 1000 Document Conferencing system is currently utilized by the Department of Defense in the strategic Defense Initiative "star Wars" program and by NASA for use in the space Shuttle Program. DataBeam systems are also used by Rockwell International, Pfizer Pharmaceutical, General Electric, General Motors, Lockheed Aircraft and the U.S. Navy and the U.S. Joint Chiefs of Staff. In 1988 DataBeam received the small Business of the Year Award by the Lexington Chamber of Commerce. Also, DataBeam was selected by the Kentucky Society of Professional Engineers to receive the 1988 Governor's New Product Award.

Projectron, Inc. is a highly successful design and manufacturing operation producing cathode ray tubes for the flight simulation industry. The unique tubes produced by projectron have illowed Rediffusion Simulation of England to capture $85 \%$ of the commercial simulator market. At projectron, now a subsidiary of Hughes Aircraft, Dr. Todd is the President and chief Executive officer.

Dr. Todd taught in the Electrical Engineexing Department at UK from 1974 to 1983 . While at UK, Dr. Todd received several teaching awards including the UK Alumni Associate Great Teacher Award. Dr. Todd has been issued eight U.S. Patents, served on the UK senate for eight years and was the faculty adviser for the University student Leadership Fraternity. Dr. Todd has been active in the Society for Information Display (SID), serving in various capacities, including chairman of the 1989 SID International symposium.

Dr. Todd is very active in encouraging the formation of other high technology companies and in the improvement of science and technology curriculum in Kentucky schools and colleges, currently, he is Chairman of the kentucky science and Technology council. 
Dr. Todd also serves as Chairperson of the Kentucky EPSCOR Committee, and serves on the Lexington Chamber of Commerce Board of Directors, the Joint UK/University of Loulsville Engineering Advisory committee, the shakertown Roundtable, UK Robotics Center Board, The Kentucky Chamber of comerce Project 21 Board of Advisory, and the Kentucky Journal Advisory Committee. Most recently Dr. Todd was named the Kentucky/Southern Indiana Inc. Magazine "Entrepreneur of the Year." 
B. Ratucky EPBCOR Project DIractor

$\begin{array}{lll}\text { Name: } & \text { John W.D. Connolly } & \text { S.S. Number: 117-34-8726 } \\ \text { Institution: UK } & \text { Department: Physics } \\ \text { Address: } & 325 \text { KcVey Hall } & \text { Telephone: (606) 257-8737 } \\ & \text { Lexington, KY 40506-0045 }\end{array}$

\section{EDOCATIONAL BACKGROOND}

Ph.D. … Physics, University of Florida, June 1966

B.A. Applied Mathematics, University of Toronto, June 1960

\section{RROFESBIONAL EXRERIENCE}

1987-present

$1984-87$

1984

$2983-84$

$1982-83$

$1981-82$

$1978-82$

$1970-78$

$1967-70$
Director of the Center for Computational sciences and Professor of Physics, UK

Director of the office of Advanced scientific Computing, National science Foundation

Section Head, Materials Research Laboratories National science Foundation

Budget Examiner, Energy and Science Division

office of Management and Budget, White House staff

Section Head, Condensed Matter Sciences

National Science Foundation

Visiting scientist

IBM Xorktown Laboratories, NY

Program Director, Condensed Matter Theory

National Science Foundation

Professor of Physics

University of Florida

Research scientist

pratt \& Whitney Aircraft corp. 


\section{BECENT POBLICATIONS}

"Band structure and superconductivity in $\mathrm{Bi}_{3}$ Sr and $\mathrm{Bi} \mathrm{I}_{3} \mathrm{Eu}$ ", Phys.Rev. B 26, 4951 (1982). With D.A. Papaconstantopoulos, B.M. Klein and I.I. Boyer.

"Density Functional Theory Applied to Phase Transformations in Transition Metal Alloys". Phys. Rev. B 275169 (1983). With A.R. williams.

"Cohesion, Compound Formation and Phase Diagrams from First Principles", in Alloy Phase Diagrams, L.H. Bennett, T.B. Massalski, Eds. (North Holland, 1983), pp 17-28. With A.R. Willams, C.D. Gelatt and V.L. Moruzzi.

"Alloy Phase Diagrams from First Principles", in The Electronic structure of Complex systems, P. Phariseau and W.M. Temmerman, Eds. (Plenum Press, 1984), Pp. 581-592. With A.R. Williams.

"The Technological Importance of supercomputers", Bell Atlantic Quarterly, Vol. II, No.4, P. 31 (1985).

"NSF and the world of supercomputers", in supercomputers, Algorithms, Architectures and Scientific computation, F.A. Matsen and T. Tajima, Eds. (University of Texas Press, 1986), pp.1-5.

"The status of the NSF program in Supercomputing", in Large scale computational Device Modeling, K. Hess, Ed. (University of Illinois, 1986), pp 1-5.

"NSFNET: A National Network for science and Engineering Research". in Control Data World, Vol. I, No. 5, pp 5-6 (1987).

"The National supercomputer Facility", in supercomputer, vol. 15, p. 4 (1987).

"Supercomputing with the IBM $3090 \mathrm{VF",} \mathrm{supercomputing} \mathrm{Review,} \mathrm{Vol.}$ 2, No. 7, Page 48 (1989).

"High Performance Computing in the world Market: Pait I", supercomputing Review, Vol. 2, No. 12, Page 38 (1989).

"High Performance computing in the world Market: Part II", supercomputing Review, Vol. 3, No. 1, Page $40(1990)$. 
C. Chadr, DOE/EPBCOR Bubcomitte

Name:

John M. Stencel

Institution:

U. of Kentucky

3572 Iron Works Pk

lexington, KX 40511

Department: center ror

Applied Energy Research

Address :

EDUCATION BACKGROUNG

Ph.D. Physics, Vanderbilt University (Nashville), 2976

B.A. Physies, St. John's University (Minnesota), 1970

PROFESSIONAL EXPERIENCE

1985-92 Manager/Associate Director, Center for Applied

Energy Research, University of Kentucky

1978-85 Research Scientist, Pittsburgh Energy Technology Conter, Pittsburgh, PA

1976-78 Postdoctoral Research Associate, University of

Kentucky

SELECTED PUBLICATIONS

2. Instrumental Analyses of Coal Ifquefaction Catajysts, by J.M. stencel, I. Polinski and V.U.S. Rao, a book chapter by invitation from Plenum Publ. Co. Introduction to the seience of coal and coal Utilization, Ea. B.R. Cooper and W.A. Ellingson (1984).

2. Raman spectroscopy for catalysis, by J.M. Stencel, Van Nostrand, Inc. (1989).

3. "Surface Metals Interactions in FCC During Upgrading of Vcontaminated Oils." by M.L. Occelli and J.M. Stencel, Proc., Int'l syop. on zeolites in catal., 9/88, wurzburg, FDR.

4) "Surfacemetals Interactions In FCC During Upgrading of VContaminated O11s", by M.L. Occelli and J.M. Stencel, Reprints, Int'l zeolite conf., $9 / 88$, Wurzburg, FDR.

5) "Physical and chemical probes for surface studies", I.M. stencel, Invited Plenary lecture, Proc., $10^{\text {th }}$ Canadian symposium on Catlaysis, Quebec, Canada, 6/15-18/86.

6) "Physical properties of Udtrafine Iron carbide Particles Generated by Iaser Pyrolysis", by X.-X Bi, P.C. EkIund, J.M. Stencel, R.E. Gonzalez, R. Srinivasan and F.J. Derbyshire, Proc. MRS-synthesis and Properties of New Catalysts, Boston, MA $(1.1 / 26,90)$.

7) "Catalytic Reactivity of Ultrafine Iron Particles Gerierated by Laser Pyrolysis", by F.J. Derbyshire, B.H. Davis, P.C. Ekiund, R.A. 
Keogh, and J.M. Stencel, Proc., MRS - Synthesis and Properties of New Catalysts, Boston, MA $(12 / 26 / 90)$.

8) "Corrosion Testing in Coal Prepartion Environments", by J.B. lieink, J.M. Stencel, R.T. Abner and R.E. Gomzalez, Proc. Corrosion 187, 3/9-13/87.

9) "Physical and Chemical Probes for surface studies", J.M. stencel, Invited Plenary Lecture, Proc., $10^{\text {th }}$ Canadian symposium on Catalysis, Quebec, Canada, 6/25-18/86.

10) The Effect of Chlorine on the in-Bed Tube wastage of Atmospheric Fluidized Bed Combustorsn, by 8 . Barnett, J. Schaefer, J. Neathery, and J.M. Stencel, J. Inst. Energy, 64, 257(1991).

PATENTS

"Two stage Chemical Pyrolysis process for production of ValueEnhanced Products from Coal", by J.M. Stencel and F.J. Derbyshire. 


\begin{abstract}
ARPENDIX III
A. "Clean Uses of Fossil Fuels Flyer

B. Traineeship Application Form and Guidelines
\end{abstract}




\section{$\$ 25$, \\ 000 \\ Doctoral Traineeships in \\ "Clean Uses of Fossil Fuels"}

The Kentucky EPSCoR Program has been awarded $\$ 250,000$ from the U.S. Department of Energy (DOE) to implement a doctoral traineeship program. EPSCoR (Experimental Program to Stimulate Competitive Research) is a unique infrastructure-building effort sponsored by various federal agencies to develop long-term improvernents in a state's science and engineering enterprise. The Kentucky DOE/EPSCoR traineeship program provides for ten $\$ 25,000$ doctoral fellowships to continuing and new students at the University of Kentucky and the University of Louisville. Each award includes an $\$ 18,000$ stipend, $\$ 2,000$ for tuition, and $\$ 5,000$ for travel and supplies.

\section{Minimum Requirements:}

0

\section{U.S. Citizenship or Permanent Resident status.}

0

Admission into a Ph.D. program at the University of Kentucky or the University of Louisville as either a continuing or new student.

0

A research plan leading to a Ph.D. in one of the following four areas:

- Carbon-Based Materials

- Catalysis

- Climate Modeling

- Environmental Impact and Bioremediation.

\section{Application Deadline:}

Application deadline for continuing students is December 2, 1991. Application deadline for new students is February 17, 1992. Applications forms should be requested from the Kentucky EPSCoR Office, P.O. Box 22302, Lexington, KY 40522, ph. (606) 257-8316. 
Kentucky EPSCoR Program

Application for DOE Traineeship

(See Reverse for Instructions and Information)

\section{Personal Information}

Name

Last First Middle

Social Security Number 1

Address

$$
\text { Street or Box }
$$

Telephone - Home $C$

Date of Birch

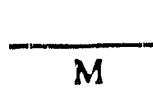

Ethnic Background: Hispanic

White/Non-Hispanic Mexican America Asian/Pacific Island
Zip Code

Orfice ( _

State of Residence

State American Indian Puero Rican Other

\section{Educational Background}

Degrees (Include any expected between now' and beginning of traineeship.)

Institution

Degree

Date Awarded

Field

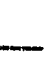

$\longrightarrow$

Acadernic Standing: Based on a 4.00 scale. $G P A=$ Grade Point A verage; U=Undergraduate: Gr=Graduate.

Overall UGPA

UGPA, Major Subject

Overall GGPA

GRE GMAT

Date Taken

Verbal Quan. Analytic

College Honors or Recognition (Include scholarships and fellowships held as an undergraduate and graduate sudent):

3. Traineeship Information

Eligibility: U.S. Ciuzenship Permanent Resident

Enrolled in Ph.D. progtam at: University of Kenlucky University of Louisville

Deparument and/or Program:

Enrollment Status:

Continuing Student

Now Student

Research Asca:

Carbon-Based Matcrials Catalysis

Climatc Modcling Environmental Impact and Bioremediation

Facully Menwer: 


\section{Kentucky EPSCoR Program \\ Doctoral Traineeships in \\ "Clean Uses of Fossil Fuels"}

The Kentucky EPSCOR Program has been awarded \$250,000 from the U.S. Deparunent of Energy (DOE) 10 implement a doctoral traineeship program. EPSCOR (Experimental Program lo Stimulate Competitive Research) is a unique infrastructurebuilding effon sponsored by various federal agencies to develop long-term improvements in a state's acience and engineering enterprise. The Kentucky DOE/EPSCOR program provides for ten $\$ 25,000$ doctoral fellowships locontinuing and new students at the University of Kentucky and the University of Louisville. Each award includes an $\$ 18,000$ stipend, $\$ 2,000$ for tuition, and $\$ 5,000$ for travel and supplies.

Minimum requirements include: 1) U.S. Citizenship or Permenent Resident status; 2) Admission into a Ph.D. program at the University of Kenwcky or the University of Louisville as either coninuing or new student; and 3) A research plan leading to a Ph.D. in one of the following four areas: Carbon-Based Materials, Catalysis, Climate Modeling, or Environmental Impact and Bioremediation. In order 10 phase in these awards, the awards will be distributed as follows: three awards 10 students with approximately one year remaining in their Ph.D. programs; three awarods to students in the midst of their graduate work; and four awards to new students entering Pt.D. programs. The normal tenure of awards other than the three one-year aw'ards to dissertation-year students would be for three years, subjecl to satisfaclory progress and the continued availability of DOE funds.

Applications for continuing graduate students should be prepared jointly by a faculty mentor and the prospective traince. In addition 10 a completed application form (see reverse), the applicant should prepare a brief description of current or proposed research in his/her own words, not we exceed 500 words. A shorter statement of the faculty mentor should indicale the working relation ship that does or will exist with the proposed trainee, and a brief discussion of the proposed research plan. The application deadline for coninuing students is December 2,1991. A wards will be arnounced by Docember 15, 1991, with suppori Lo be'gin in January 1992.

Applications for new graduate students should be prepared by the faculty mentor. In addition to a completed application form (see reverse), the faculty mentor should submit a graduate study plan including the proposed area of study, courses to be taken, and extent of research training. The relationship of this plan wo one or more of the subtheme areas should be clarified. The application deadline for new students is February 17, 1992. Awards for new students will be announced by March 1, 1992. with suppor to begin in August 1992.

All applications should include a brief vita of the mentor, showing only the five most recent and relevad publications, together with the total num ber of all publications in refereed jouraals, and the proposal and funding bistory of the mentor for the last five years.

Factors enhancing success will be: 1) an extraordinary academic record; 2) a well-planned description of existing or proposed research for continuing students or a well-planned educational program for new students; and 3) a research developmental plan which inciudes suong linkages to one of the DOE muluprogram laboratories.

Complated applications should be submilled to the Kentucky EPSCOR Office, P.O. BOx 22302, Lexington, KY 4052?, ph. (606) $257-8316$. 
APPENDIX IV

PROPOBAL REVIET PANEL 
Dr. John Connolly (Chair), University of Rentucky: Director, Center for Computational sciences.

Dr. Frank Derbyshire, University of Kentucky; Director, Center for Appliec Energy Research.

Dr. Thomas Hanley, University of Louisville: Dean, Speed scientific school.

Dr. Harrell Hurst, University of Louisville; Associate Professor, Pharmacology.

Dr. John Kielkopf, University of Louisville; Professor, Physics.

Dr. Lee Magid, University of Kentucky; Vice President, Research a Graduate studies.

Dr. Marc McEllistrem, University of Kentucky: Department of Physics.

Dr. John Riley, Western Kentucky University; Director, Center for coal science.

Dr. Wimberly Royster, University of Kentucky: Special Assistant 0 the President.

DI. Joseph steffen, University of Iouisville; Department of Biology.

vr. John Stencel, University of Kentucky; Center for Applied Energy Research. 
$\mid$

APPENDIX V

RESUNEB OF FACOLTY HENTORS 


\section{Ronald X. Atlas}

Professor of Biology

Department of Biology

University of Louisville, Louisville, KY 40292

\section{GRANTS AND CONTRACTB}

Perkin-Elmer-Cetus: $9 / 1 / 89-8 / 31 / 90$ \$60,000 (PI - R. M. Atlas; CoPI - R. Miller) Development of PCR Detection Methods for Environmental Monitoring of Coliform and Legionella Bacteria.

Perkin-Elmer-Cetus: $9 / 1 / 90-8 / 31 / 91$ \$60,000 (PI - R. M. Atlas) Development of $P C R$ Detection Methods for Environmental Monitoring of Coliform and Leaionella Bacteria.

EXXON: $7 / 1 / 89-5 / 1 / 90 \$ 150,000$ (PI - R. M. Altas) Microbial EXXONValdez Environmental Assessment Program.

EXXON: 5/1/90-7/1/90 $\$ 150,000$ (PI - R. M. Altas) Microbial EXXONValdez Environmental Assessment Program.

EXXON: 7/1/91-12/31/91 \$65,000 (PI - R. M. Altas) Microbial EXXON-Valdez Environmental Assessmert Program.

\section{BOBLICATIONS}

over 160 journal articles coauthored by Ronald M. Atlas

Bej, A. K., M. H. Perlina nd R. M. Atlas. 1988. Model suicide vector for containment of genetically engineered microorganisms. Appl. Environ. Microbiol. 54:2472-2477.

Bej, A. K., S. Molin, R. M. Atlas, and M. Perlin. 2991. Conditional lethal constructs in Escherichia coli and in pseudomonads using hok and gef genes. J. Indust. Micro. submitted.

Bej, A. K., M. Perlin, and R. M. Atlas. 1991. Effect of introducing genetically engineered microorganisms on soil microbial community diversity. FEMS Microbiol. Ecol. in press

Steffan, R. J. and R. M. Atlas. 1988. DNA Amplification to Enhance the Detection of Genetically Engineered Bacteria in Environmental Samples. Apol. Environ. Microbiol. 54:21852191.

Steffan, R. J., J. Goksoyr, A. Bej, and R. M. Atlas. 1988. Recovery of DNA from Soils and Sediments. Appl. Environ. Microbiol. 54:2908-2915. 


\section{PERSONAL DATA}

Name: Dorothy H. Gibson

Department: Chemistry

Institution: University of Louisvilie

Address: $\quad$ Chemistry Building 0138

Louisvilie, Ky 40292

\section{EDUCATIONAL BACKGROUND}

Ph.D. Chemistry (Organic/organometallic), University of Texas (Austin), 1965

M.A. Chemistry (Organic), Texas Christian University, Ft. Worth, TX 1956

B.A. Chemistry, Texas Christian University, Ft. Worth, TX 2954

PROFESSIONAL EXPERIENCE

1978-87 Vice-Chair, Chemistry, University of Louisville

1982-83 Acting Chair, Chemistry, University of Louisville 1975-present Professor of Chemistry, University of Louisville

1971-75 Associate Professor of Chemistry, University of Louisville

1969-71 Assistant Professor of Chemistry, University of Louisvilie

1965-69 Postdoctoral Associate of Chemistry, University of Colorado, Boulder, Colorado

1964-65 Postdoctoral Associate of Chemistry, University of Texas, Austin, $\mathrm{TX}$

FIVE RELEVANT PUBIICATIONS

1. Synthesis of Iron Aryl Phosphonate Complexes, Dorothy H. Gibson, Tek-sing ong, Ming Ye, Jaime 0 . Franco and Kathryn owens, organometallics, 7, 2569 (1988).

2. Synthesis and Thermolysis of Neutral Metal Formyl Complexes of Molybdenum, Tungsten, Manganese and Rhenium, Dorothy $\mathrm{H}$. Gibson, Kathryn Owens, Santosh K. Mandal, Jaime O. Franco and William E. Sattich, Organometallics, B, 498 (1989).

3. Synthesis of Halomethyl complexes from Metal Formyls, Dorothy J. Gibson, Santosh K. Mandal, Kathryn Owens, William E. Sattich and Jaime O. Franco, organometallics, 8, 1114 (1989). 
4. Synthesis and Characterization of Manganese and Rhenium Metallacycles, Dorothy H. Gibson, Kathryn Owens, Santosh $K$. Mandal, William E. Sattich and John F. Richardson, Organometallics, 9, 424 (1990)

5. Synthesis and Characterization of secondary Carbene Complexes of Manganese and Rhenium, Dorothy H. Gibson, Santosh K. Mandal, Kathryn Owens and John F. Richardson, Organometall1Cs, 9, 1936 (1990). 


\title{
current Position Assistant Professor of Inorganic Chemistry
}

Business Department of Chemistry

University of Kentucky

Lexington, KY 40506-0055

\section{Education}

B.A.., (summa cum laude in Chemistry), Benedictine college, 1979

Ph.D., University of Rochester, 1.984

Thesis: "Studies of Electron Transfer Reactions," (G.I. McLendon)

\section{Professional Experionce}

Postdoctoral Research Fellow, Department of Chemistry, California Institute of Technology, 1984-86

Assistant Professor of Chemistry, University of Kentucky, 1986-present

\section{Professional Activities}

\author{
American Chemical society \\ Sigma Xi \\ Kentucky Academy of Science \\ Electrochemical Society
}

Eonors

Sherman Clarke Fellowship, 1979-83

Elon Huntington Hooker Fellowship, 1981

University of Kentucky special Summer Faculty Fellowship, 1989

Belected Relevant Publications (Ilve most recent)

H. Ii and T.F. Guarr, "Electrochemistry at Modified Electrodes: Electronically Conductive Metallophthalocyanine Coatings," synth. Met., 38, 243-251. (1990).

H. Li and T. F. Guarr, "Reversible Electrochromism in Polymeric Metal. Phthalocyanine Thin Films," J. Electroanal. Chem., 297, $169=183$ (1991).

X. Qi, R.P. Baldwin, H. Ii and T.F. Guarr, "Electrocatalytic Amperometric Detection at Polymeric Cobalt Phthalocyanine Electrodes," Electroanaysis, 3, 119-124 (1991). 
E.M. Baum, H. LI, T.F. Guarr, and J.D. Robertson, Characterization of Electrochemically Polymerized Metal Phthalocyanines Using Rutherford ackscattering spectrometry," Nucl. Inst. Methods, B56/57, 761-763 (1991).

H. II and T.F. Guarr, The Electrocatalytic oxidation of oxalic Acid at Electrodes coated with polymeric Metallophthalocyanines," J. Electroanal. Chem., 317, 189-202 (1991).

A Total of 20 publications in refereed journals.

\section{Punded Proposals (last Iive gears)}

1. "Kinetics of Competitive Long-Range Electron and Hole Transfer Reactions," American Chemical Society, Petroleum Research Fund, $\$ 18,000,9 / 1 / 87-4 / 30 / 90$.

2. Purchase of an Excimer Laser system, (with D.J. Clouthier and F. J. Holler), University of Kentucky Bond Issue Equipment Fund, $\$ 34,350,4 / 1 / 87$.

3. Purchase of an Electrochemical Station, (with J. P. Selegue), university of Kentucky Bond Issue Equipment Fund, \$27,300, $4 / 2 / 87$.

4. Summer Research Fellowhsip, University of Kentucky Graduate School, $\$ 2,400,5 / 87-8 / 87$.

5. "A Critical Test of the Superexchange Mechanism of Electron Transfer," Research Comittee, University of Kentucky, $\$ 3,200$, 1987.

6. "Electrochemically controlled Drug Release From Redox Polymers," National Institutes of Health Biomedical Research support Grant, $\$ 3,500,1987$.

7. MElectrochemically controlled Permeability of Polymer Membranes," National Institutes of Health Biomedical Research support Grant, $\$ 2,149,7 / 1 / 88-3 / 31 / 89$.

8. Purchase of a Laser wavelength Extension system, (with J. R. Appling and $D$. J. Clouthier), University of Kentucky Major Equipment fund, $\$ 21,750,12 / 1 / 88$.

9. Purchase of a Luminescence spectrometer, (with L. G. Bachas), University of Kentucky Major Equipment Fund, $\$ 27,900,12 / 1 / 88$.

10. ACS-PRF Summer Research Fellowship (Supplementary Funds to \#1), $\$ 4,500,6 / 1 / 89-8 / 31 / 89$.

11. "The Formation and properties of Novel Inorganic conducting Polymer;," Research Committee, University of Kentucky, $\$ 3,630$, $1 / 1 / 89-6 / 32 / 89$. 
12. Special sumwer Faculty Feliowship, University of Kentucky Fund for Excellence, $\$ 5,000,2989$.

13. "Electronic Properties of Multimetailic complexes: A Potential Route to Solar Energy storage?n American Philosophical soclety, $\$ 2,500,1 / 1 / 90-12 / 31 / 90$.

14. MElectrochromic Display Device Employing a Thin Pilm of a Polymeric Cobalt Fhthalocyanine, "Research Corporation (option payment), $\$ 1,000,7 / 1 / 90-6 / 31 / 92$.

15. "Structure-Activity Relationships in Chemical Catalysis," National science Foundation EPSCOR Program, - $\$ 106,000$ (this PI's Component), 2/15/92-2/14/95.

16. "Preparation and Properties of Low-Dimensional Conductors and Their Intercalates," National science Foundation EPSCoR Program, $-\$ 95,000$ (this PI's component), 2/15/92-2/14/95.

17. "Electrochemistry at Phthalocyanine-Modified Electrodes," National Institutes of Health, $\$ 517,213$, pending.

18. "Preparation and Characterization of Novel PhthalocyanineBased Conductive Polymers," (J. D. Robertson and J. M. stencel, co-pIs), National science Foundation, $\$ 621,005$, pending.

19. Membrane-Based Catalytic Decomposition of Mazardous Chlorinated Aromatic Compounds," (D. Bhattacharyya and $[$. Alian Butterfield, PIs), Kentucky Environmental Protection Agency EPSCOR Program, submitted. 


\section{Mine Bumphi11 \\ ondversity of Loulsvil10}

Educetion:

$\begin{array}{ll}\text { B.A. } & \text { University of Pennsylvania, cum laude. } 1976 . \\ \text { M.A. } & \text { University of Pennsylvania, 1977. } \\ \text { Ph.D. } & \text { University of California, Santa Barbara(UCSB)-1989 }\end{array}$

Profeselonal Experience:

Assistant Professor, Department uf Biology/Water Resources Laboratory, University of Louisville, 1989-present.

\section{Granta:}

Hemphili, N. Interactions between stream flow and predator effects. National science Foundation. 1991-93. \$17,925.

\section{Publ1cat1ons:}

Hemphill, N. 1991. Disturbance and variation in competition between two streain insects. Ecology 72:864-872.

Hemphill, N. 1988. competition between two stream dwelling filterfeeders, Hydropsyche oslari and simulium virgatum. Oecologia $77: 73-80$.

Hemphill, N. and S.D. Cooper. 1983. The effect of physical disturbance on the relative abundance of two filter-feeding insects in a small stream. Decologia 58:37.

Hemphill, N. 1983. The Aquatic Fauna of The Streams, chapter 3 from The Proposed Corps of Engineers Flood Control and Ground water Recharge Project for the Goleta Valley, Santa Barbara County, California: Inventories of the Biological Resources of the Affected Creeks and an Analysis of the Effects on the creeks and the Goleta slough.

Cooper, S. and N. Hemphill. 1984. Upper Mission Creek and Rattlesnake Creek Aquatic Resources with an Impact Assessment of a Proposed Flood control Project and Mitigation Recommendations. Technical Report prepared for U.S. Fish ard Wilalife Service.

Total Number of refereed papers: 5 
Chemical Engineering Department, University of Iouisville Louisville, KY 40292, USA - 502-588-6350, FAX 502-588-6355 e-mail: romiraoleulkyvm.bitnet

\section{Educat1on:}

Ph. D.

University of connecticut

1983

M.S.

University of connecticut.

Ing.

- University of

cuyo, Argentina

1975

\section{Meadomic ixperienoe:}

1989-present

Associate Professor

Chemical Engineering, University of Louisville Director, Materials Research Laboratory

$1983-89$

Assistant Professor

1989 Chemical Engineering, University of Louisville

2977

Visiting Professor, Inst. of Materials Science, Universidad de Mar del Plata, Argentina.

Adjunct Professor of Applied Mathematics

Universiaad Techologica Nacional, Argentina.

$1972-75$

Instructor of Industrial Chemistry, Escuela de Bachillerato Techico-Quimico, Mendoza, Argentina.

Industrial Experionca:

$1984-87$

Visiting scientist at Argonne National Laboratory and DOE's Pittsburgh Energy Technology Center

$1976-77$

Plant Engineer, Compania Minera Aguilar, Argentina

\section{Professional Memberahip:}

American Chemical Society, Materials Research society, American Ceramic Society, American vacuum society

\section{Bonorary Pellowships and Awards:}

Thesis Fellowship-Yacimientos carboniferos Fiscales, Argentina, 1973

Industrial rraineeship-Confederation of British Industry, 1974

Graduate study Fellowship-organization of American States, 1978

Doctoral Fellowship-University of Connecticut Research Found

Hororable Mention-U. of $L$. President's Initiative for Research Award, 1988

U. of L. President's Young Investigator Award, 1989 


\section{Recent Joural publications:}

R. Miranda, J.S. Chung, C.O. Bennett, Intermediates and Elementary steps in the Selective oxidation of Methanol on High Surface Area Molybdenum Oxides. In Proc. 8 th Internat. Congr. Catal., Berlin, 1984, III-347-57; springer-Verlag (Dechema).

R. Mirancia, D.J. Colilins, B.H. Davis, Catalytic Conversion of Alcohols. Role of sodium in Altering the Alkene Products obtained with Alumina Catalysts. J. Catalysis 88, 542-5 $(1984)$.

J.S. chung, R. Miranda, C.O. Bennett, A Study of Methanol and Water Chemisorbed on Finely Divided Mo03. J. Chemical Soc. Farad. Trans., 1, 81, 19-36 (1985).

J.S. chung, R. Miranda, C.O. Bennett, Mechanism of Partial oxidation of Methanol. J. Catalysis 124, 398-410 (1988).

D.J. Collins, E.C. Lloyd, R. Miranda, Side Reactions in Quinoline HDN. Aplied catal. 41, 81-8 (1988).

R. Miranda, A Course in Heterogeneous Catalysis, Chemical Eng. Educ., Chem. Eng. Educ. 23, 116-119 (1989).

R. Miranda, S.A. Kareem, supported and sulfided Pb-Mo Oxides: Active and stable Hydrotreatment Catalysts, Catal. Lett. 1, $217-22$ (1988).

S.A. Kareem, R. Miranda, Hydrodesulfurization Catalysis over Ternary Molybdenum Charcogenides, J. Molecular Catal. 53, 275283 (1989).

S. Rajagopal, T.L. Grimm, D.J. Collins and R. Miranda, A Practical Scheme for the GC Analysis of Pyridine Hydrodenitrogenation Reaction Products, Anal. Lett. 23,649-657 (1900).

S. Rajagopal, T.I. Grimm, D.J. Collins and R. Miranda, Denitrogen ation Reactions of Piperidine over Silica-Aluminas, J. Catal., accepted (1992).

R.ochoa, R. Miranda, W.F. Huang, Positron Annihilation study of Catalysts, (Prod. 3rd Int. Workshop on Positron and Positronium Chemistry, Hilwaukee, WI, Sep 16-18, 1990), World Sci. Publ., pp. 584-92.

W.F. Huang, R. Ochoa and R. Miranda, Positronium-Bronsted Site Interaction in Silica-Alumina Catalysts, Physics Letters A $158,417-424$ (1991).

R. Miranda, R. Ochoa, W.F. Huang, Perspectives of Positron Annihilation spectroscopy in Heterogeneous Catalysis, J. Molec. catal., accepted (1992). 
R. Miranda, "Interfaces between Ferroelectric Ceramics-Non-Noble Metals: A Review", J. Materials Research, accepted. 


\section{Imox-ma1 vig}

Mddress: Department of Physics and Astronomy

Rin. 177 Chemistry-Physics Building

University of Kentucky

Lexington, Kentucky 40506-0055

sducation: University of Hong kong

B.sc. in Physics, 1981.

Iowa state University

Ph.D. in Solid state Physics, 1986

careex: Teaching Assistant 1981-83

Department of Physics, Iowa State University

Research Assistant 1983-86

Ames Laboratory, USDOE, Iowa State University

Postdoctoral Fellow 1986-88

Physics Department

University of Texas, Austin

Assistant Professor 1988-present

Department of Physics and Astronomy

University of Kentucky, Lexington

Membership: American Physical society

The Institute of Electrical and Electronics Engineers

Phi Kappa Phi: National honor society

Extramural

NSF (July 1.989 - June 1992, \$130,000)

Bupporta:

"Extensive studies of High TC superconductors with tunneling methods"

Five Most Relevant Publications:

K. W. Ng, z. g. Knim, Danny P. Shum and E. I. Wolf Vacuum tunneling of thin film and bulk polycrystalline superconductors. surface science, 281 (1987) pp37-45.

K. W. Ng, S. Pan, A. I. de Lozanne, A. J. Panson and J. Talvacchio Tunneling spectroscopy of bigh $I_{\text {axide superconductors with a }}$ scanning tunneling microscope Jap. J. Appl. Phys. 26 suppl. 26-3 (1987) pp993-994.

A. L. de Lozanne, K. W. Ng, S. Pan, R. M. Silver and A. Berezin Tunneling spectroscopy of $\mathrm{High} \mathrm{I}$ superconductor $\mathrm{J}$. Microscopy 152 p.t. $2(1988)$.

sijia wu and $\mathrm{K}$. W. Ng A Piezoelectric priven Micropositioner with Magnetic Locking Mechanism Rev. Sci. Instrum. 62 (1991) pp93-95. 
Q. Chen anu K. W. Ng Gap Anisotropy of $\mathrm{Bi}_{2} \mathrm{Sr}_{2} \mathrm{CaCu}_{2} \mathrm{O}_{\mathrm{f}}$ Measured by Iow Temperature scanning Tunneling Microscope Submitted to Phys. Rev. B. 
PERsonay, DATA

Rank:

Institution:

Department:

Address :

Associate Professor

University of Kentucky

Geological sciences

253 Bowman Hall

Lexington, KY 40506-0059

\section{EDOCATIONAL BACXGROUND}

Ph.D. Geology 1985 Pennsylvania state University, University Park, PA

M.S. Geology 1978 University of IIlinols, Urbana, IL

B.S. Geology 1975 Southern Illinois University, Carbondate, II

A.A. Liberal Arts 1973 Southwest Junior College, Chicago, IL

\section{RROPEBSIONAL EXPERIENCE}

1989-present Associate Professor, Geological Sciences, University of Kentucky

1990-1991 Faculty Associate, Center for Applied Energy

1985-1989 Assistant Professor, Geological Sciences, University of Kentucky

1984-1985 Instructor, Geology, University of Kentucky

1983

1983

1982

$1979-1983$ Research Fellow, Coal Research section. Penn state Adjunct Instructor, Juniata College, PA Techrical Editor, DOE Program, Coal Research Section, Penn state

$1978-1979$

$1975-1978$

Graduate Research Assistant, Coal Research Section, Penn State

Special Research Associate, Coal section, Illinois State Geological Survey

Research Assistant, coal section, Illinois state Geological survey

\section{PROFEBSIONAL ACTIVITIEB AND RONORB}

Professional Memberships: The Society for Organic Petrology (TSOP); Clays and Clay Minerals Society; Geological society of America-Coal Geology Division; Society of Economic Paleontologists and Mineralogists.

offices Held/Comnittee service: The society for organic Petrology (TSOP): President (1991-92). President-Elect (1990-91), Vice-President (1989-90), Treasurer/secretary (1986-89), co-Host 3rd. Annual Meeting (Lexington) (1986), Co-Host 8 th Annual Meeting (Lexington) (1991): Geological society of America: Campus Representative (1989 to present), Coal Geology Division secretary (1987-1990), Best Paper Committee - Annual Meeting 1989.

Editorial Board of the International Journal of Coal Geology (since 1991): occasional reviewer Journal of Sedimentary Petrology and organic Geochemistry. 
Phillips Petroleum Research Fellow (1983), Sigma Xi.

\section{FONDING (INBT IIVB YBARB ONLY)}

1992

$\$ 10,000$

1992

237,549

1991

2991

$1990 / 91$

1989

10,000

1989

8,160

1987

28,000

$198^{\prime \prime}$

125,000 merganic Maturation Studies, Amoco Oil Company, Houston, TX. "Carbon Synthes is from Coal and Maceral concentrates." DOE/PETC (Pending) (Collaboration with CAER). "clay Mineralogy of Underclays." Potomac Mining $\mathrm{CO}$, Lexington, $K Y$.

"Effects of overpressure on erganic Maturation Parameters," Shell Developmen $t$ Company, Houston, $T X$.

"Clay Mineral Analysis of Bottom Sediments, Gulf of st, Lawrence." University of Windsor, Ontario, canada. Modes of Occurrence of Trace Elements in Macerals and Minerals from the Blue Gem coal Bed: Application of Density Gradient centrifugation and Electron Microprobe Technioues." U.S. Bureau of Mines.

"Ash-Fusion Characteristics of Kentucky coals." Jointly funded by U.S. Bureau of Mines, IMMR, and the Kentucky Geological survey.

Zeiss Quantitative spectral Fluorescence system, University of Kentucky, Bond Issue Funds

Rigaku Rutomated X-ray Diffraction system, University of Kentucky, Bond Issue Funds

\section{POBLICATION8}

Total of 17 refored publications

Five most recent and relovant publications:

Rimmer, S.M.; Thwaites, M.W.: Jagtoyen, M.: Stencel, J.: McEnaney, B.: and Derbyshire, F.J.: 1991, Optical Microscopy of CoalDerived Activated Carbons: Preliminary Results: 8th Annual Meeting, The Society for organic Petrology, Abstracts and Program, septembex 30-october 1, 1991, Lexington, KY.

Derbyshire, F. J.; Jagtoyen, M.: McEnaney, B; Rimmer, S.M.; stencel, J.M.: and Thwaites, M.W., 1991, Adsorbent carbons from coals by chemical activation: Proceedings, 1991 International Conference on Coal Science, Newcastle-Upon-Tyne, England (Extended Abstract).

Rubel, A.M.; Rimmer, S.M.; Keogh, R.; Robl, T.L.: Carter, S.D. i and Derbyshire, F.J., 1991, Effect of process folids on secondary reactions during oil shale retorting: ruel, $v .70$ (11), P. 1352-1356. 
Rimmer, S.M., 1991, Distributions and associations of selected trace elements in the Lower Kittanning seam, wstern Pennsylvania, U.S.A.: International Journal of Coal Geology, v. 27 P. $189-212$.

Hower, J.C. and Rimmer, S.M., 1991, coal rank trends in the central Appalachian coalfied: Virginia, West Virginia, and Kentucky: organic Geochemistry, v. 17, p. 161-173. 


\section{J. Devid noberteon}

\section{currant position:}

Assistant Professor, Department of Chemistry

Faculty Associate, Center for Applied Energy Research

susibess: Department of Chemistry

University of Kentucky

$\therefore$ Lexington, KY 40506-0055

zoucation

B.S., University of Missouri, 1982

Ph.D., University of Maryland, 1986

postáoctoral Fellow, Lawrence Berkeley Laboratory, 1987-89

\section{Professional Experience}

Postdoctoral Fellow, Lawrence Berkeley Laboratory, 1987-89 Assistant Professor, University of Kentucky, 1989-present

Profasional Mctivities

The American Chemical society

The American Physical society

Phi Kappa Phi

Phi Beta Kappa

\section{Honors}

University of Missouri Curators Scholarship, 1978-1982

American Institute of Chemists "Outstanding Senior

Undergraduate" , 1982

University of Maryland Graduate Fellowship, 1985

\section{Belected Research Publications:}

W. D. Ehmann, J. D. Robertson, and $S$. W. Yates, "Nuclear and Radiochemical Analysis," Anal. Chem., 62, 50R-70R (1990).

J. D. Robertson, J. B. Bates, N. J. Dudney, and R. A. Zuhr, "Ion Beam Analysis of Lithium-Ion Conducting Amorphous Electrolyte Films," Nucl. Instr. and Methods, B56/57, 722-725 (1991).

E. M. Baum, H. Li, T. F. Guarr, and J. D. Robertson, "Characterization of Electrochemically Polymerized Metal Phthalocyanines using Rutherford Backscattering spectrometry," Nucl. Instr. and Methods, B56/57, 761-763 (1991).

V. Majidi and J. D. Robertson, "Investigations of High Temperature Reactions on solid substrates with Rutherford Backscattering spectrometry: Interaction of palladium with selenium on Heated Graphite Surfaces," to appear in spectrochimica Acta (1991). 
A.S. Wong, E.A. Lurding, J.D. Robertson and H. Francis, "Determination of Fluorine in Coal and Coal Fly Ash by ProtonInduced Gamma-Ray Emission Analysis," to appear in the proceedings of The 2nd Int. Conf. on the Elemental Analysis of Coal and Its ByProducts, G. Vourvopoulos, editor (1991).

Total number of paperg in retereed fournale, 26.

\section{Grants and contracts}

"Nuclear" Methods in Chemical. and Biological sciences, "National Science Foundation EPSCOR Grant RII-8110671 and the Kentucky EPSCOR Program, \$759,141 (\$153,000 direct), 1986-1991.

"A New Method for Determining Absorption Rates of Transdermal Drug Delivery Systems," Biomedical Research support Grant BRS6 S07 RRO7114-21, \$2.500, 7/1/89-3/31/90.

"Trace-Element composition of the Bone Tissues of Alzheimer's Disease Patients," University of Kentucky sumer Faculty Research Fellowships, $\$ 2,400,6 / 1 / 90-9 / 1 / 90$.

"In-Vivo Transdermal Drug Absorption Measurements Using X-Ray Fluorescence," The Upjohn Company, $\$ 50,000,6 / 1 / 90-5 / 31 / 91$.

"Assessment of the Extent of Fires Found in Abandoned Mine Lands using Non-Invasive Tracer Techniques," U.S. Bureau of Mines, J0290004, $\$ 149,997$ (\$10,600 direct), 9/24/90-9/24/92.

"Coolside Waste Management Research," Department of Energy, DEAC21-91MC28162 and Ohio Coal Development office, $\$ 846,524(\$ 92,411$. direct), 7/91-6/95.

"An Investigation of High Temperature Reactions on Graphite Surfaces," University of Kentucky Research Comittee Grant, $\$ 1,500$, $7 / 91-6 / 92$.

"The Trace-Element Composition of the Bone Tissue of Alzheimer's Disease Patients," Alzheimer's Association, \$22,715, 12/91-11/92. 


\section{Jobs R. Belegue}

current Postition: Professor

Businase :

Department of Chemistry

University of Kentucky

Lexington, KY 40506-0055

soucation

B.S., Miami University, oxford, Ohio, 1974

Ph.D. Massachusetts Institute of Technology, Cambridge, Massachusetts, 1979

\section{Proressional Bxperienco}

Instructor, Experimental study Group (MIT):

organic Chemistry, 1975

General Chemistry, 1977

organic and General Chemistry Tutor, specia? ropics Seminars, 1978

Postdoctoral Associate, Yale University, New Haven, Connecticut, 1978-80

Assistant Professor. University of Kentucky, Lexington, Kentucky, 1980-86

Associate Professor, University of Kentucky, Lexington,

Kentucky, 1986-present
Alexander von Humboldt Research Fellow, Max-PlanckInstitute fur Kollenforschung, Mulheim a.d. Ruhr, West Germany, 1987-1988

\section{Pxofessional Activities}

American Chemical Society, Inorganic Division, organometallic and solid state subdivisions

Sigma $X i$

Kentucky Academy of science

Tri-state catalyst club

Phi Beta Kappa

Bonors

Phi Eta sigma, 1971

Gamma Theta Phi, 1973

Phi Beta Kappa, 1973

"1809 Club Award," 1973

sigma $X i, 1974$

American Institute of Chemists Award, 1974

National science Foundation Graduate Fellow, 1974-77

Alexander von Humboldt Foundation Research Fellow, 198788 
Total 39 Publinations in PIInt and submittod. Five Recent, Relevant Publications:

1.

A. K. MCMullen, J. P. Selegue and J.G. Wang, "Synthesis and structure of Tungsten $\eta^{3}-$ Enynyl Complex Resulting from Facile Alkynyl-vinylidene coupling," organometall1cs, $10,3421-3423$ (1991).

2. S. L. Ren, Y. Wang, A. M. Rao, E. MCRae, J. M. Holden, T. - Hager, K.A. Wang, W. T. Lee, H. F. N1, J. P. Selegue and P. C. Eklund, "Elilipsometric Determination of the Optical Constants of $C_{60}$ (Buckminsterfullerene) Films," Appl. Phys. Let. , 59, 2678-2680 (1991).

3.

G. A. Koutsantonis and J. P. Selegue, "Synthesis and structure of $\left[\left(R u(C O)_{2}(C p)\right]_{2}(\mu-C \& C)\right]$, an Ethynediyl Complex Formed During Tungsten-Catalyzed Alkyne Metathesis," J. Am. Chem. Soc., 113, 2316-2317 (1991).

4.

K. G. Frank and J. P. Selegue, wruthenium-Tungsten and Iron-Tungsten Complexes with Ethynyl or Ethynediyl Bridges, "J. Am. Chem. Soc., 112, 6414-6416 (1990).

5.

M. S. Meier and J. P. Selegue, MEficient separation of $C_{60}$ and $C_{70^{\circ}}$ Gel Permeation Chromatography of Fullerenes Using 100 \& Toluene as Mobile Phase," J. Org. Chem., in press (1991).

Total of 37 publications, plus soveral manuscripts in preparation.

Research ruading, 2986-1991

1.

"Metallacumulenes and Carblde complexes," U.S. Department of Energy, Office of Basic Energy Sciences, $\$ 160,000$, $9 / 1 / 85-8 / 31 / 86$.

2.

"Consortium for Fossil Fuel Liquefaction science," (Coinvestigator with five others from U.K.), U.S. Department of Energy, Pittsburgh Energy Technology Center, $\$ 135,000$, $9 / 1.185-12 / 4 / 86$.

3. "Ruthenium Chemistry: Precious Metal Chemicals," Colonial Metals Inc., ca. $\$ 300,1986$.

4. "Metallacumulenes and Carbide Complexes," U.S. Department of Energy, Office of Basic Energy Sciences, $\$ 108,000$, $9 / 1 / 86-4 / 30 / 88$.

5. "Consortium for Fossil Fuel Liquefaction Science," (Coinvestigator with five other from U.K.), U.S. Department of Energy, Pittsburgh Energy Technology Center, ca. $\$ 190,000,10 / 2 / 86-9 / 30 / 87$. 
Mlectron Transfer Processes in the Formation and Rearrangement of Two-Carbon Ilgands," National Science Foundation, EPSCOR Program, $\$ 43,064,10 / 15 / 86-10 / 14 / 91$.

7.

"Electrochemical station," (with $T$. F. Cuarr), UK Bond Issue Equjpment Grant, $\$ 27,300,3 / 16 / 87$.

8.

"Neslab UIT-80 Cold Bath/Circulator," UK Bond Issue Equipment Grant, $\$ 5,000,3 / 16 / 87$.

9.

"Braun Dry Box (matching funds)," UK Bond Issue Equipment Grant, $\$ 7,000,3 / 26 / 87$.

10.

"Matrix Isolation Apparatus," (Principal Investigator: D. $\mathrm{J}$. Clouthier), U.K. Bond Issue Equipment Grant, $\$ 19,500$, $3 / 16 / 87$.

21.

Research Fellowship, Alexander von Humboldt Foundation, ca. $\$ 20,000,9 / 1 / 87-8 / 31 / 88$.

12.

"Metallacumulenes and Carbide Complexes," U.S. Department of Energy, office of Basic Energy sciences, $\$ 242,023$, $5 / 1 / 88-6 / 30 / 91$.

13. "Interactions of Transition-Metal complexes with oxiranes: putative Models for Cytochrome-catalyzed Epoxidation of Olefins," National Institute of Health, Biomedical Research Grant Program, $\$ 3,200,7 / 1 / 89-$ $6 / 30 / 90$.

24.

"Transition Metal Complexes of Fulierenes or Thiophenes," Center for Applied Energy Research, $\$ 20,000,7 / 1 / 90$ $6 / 30 / 92$.

15.

"Metallacumulenes and Carbide Complexes," U.S. Department of Energy, office of Basic Energy sciences, $\$ 221,320$, $7 / 2 / 91-6 / 30 / 92$.

16.

"Acquisition of a High-Field Nuclear Magnetic Resonance spectrometer," (D. A. Butterfield, M.S. Mejer, K. Niedenzu, $D$. S. Watt, co-PI's), National science Eoundation, $\$ 93,046,7 / 1 / 91-6 / 30 / 92$.

Rending proposals

1.

"Waters High Performance/Gel Permeation Chromatography system," (CO-PI with Professors M. S. Meier and Peter EkIund), UK Major Research Equipment Competition, $\$ 37.840,2991$, pending.

2.

Chemical and physical studies of the fullerenes and Their. Derivatives," (P.C. Eklund, M. S. Meier, J. D. Robetson, co-PI's), National science foundation, $\$ 2,066,969,5 / 92-$ 4/95, pending. 


\author{
APPENDIX VI \\ MEMORANDOW OF AGREEMENT \\ BETTEEN \\ KENTUCKY BCIENCE AND TECHNOLOGY COUNCIL, INC. \\ RND \\ RENTOCKY EPBCOR CONOITTEE
}




\section{MEMORANDUM OF AGREEMENT \\ BETWEEN \\ THE KENTUCKY SCIENCE AND TECHNOLOGY COUNCH, INC. \\ AND \\ THE KENTUCKY EXPERDMENTAL PROGRAM TO \\ STIMULATE COMPETTTIVE RESEARCH}

\section{Purpose}

This Agreement is entered into in furtherance of the mutual goals of the Kentucky Science and Technology Council, Inc. (hereinafter "KSTC") and the Kentucky Experimental Program to Stimulate Competitive Research (bereinafter "EPSCOR") to provide strategic leadership, better coordination of programs and more efficient utilization of resources in the promotion of science, technology and innovative economic development in Kentucky. This Agreement provides a framework for the integration of KSTC and EPSCOR into a single entity to develop and implement comprehensive statewide programs, policies and services in education, scientific research and economic development.

\section{Recitals}

WHEREAS, KSTC is a private nonprofit corporation comprised of leaders from education, government and the private sector established (1) to propose policies and develop programs for the enbarcement of science and technology in Kentucky, (2) to serve as an advocacy group on science and technology issues; (3) to advocate the fundamental 
importance of science and technology to Kentucly's future; and (4) to stimulate technologybased development.

WHEREAS, EPSCOR is a federally created state project to (1) promote and support competitive reseajch and development in the state (2) advance science education and (3) enhance the rechnological capacity of Kentucky,

- NOW, THEREFORE, in consideration of the mutual gaals, promises, and covenants set cant herein, the parties hereto agree as follows.

\section{Terms of Agreement}

1. EPSCOR shall be a quasi-independent program of the Kentucky Science and Technology Council, Inc. In this capacity, the EPSCOR Committee (program) shall, subject to the concurrence of the KSTC, retain the authority to:

a. Hire and manage EPSCOR Project Staff;

b. Establish and administer the policies and procedures (consistent with YSTC's operating policies and procedures) governing the EPSCOR program and the awarding of $R \& D$ grants; and 
c. Appoint the members and elect the leadership of the EPSCOR Committee(s).

2 KSTC in return agrees to:

a. Adbere to the goals and mission of the EPSCoR program;

b. Expand the link from educational, university, government and private sector resources to EPSCOR;

c. Provide direct assistance in the development and implementation of programs related to education, economic development and research and development.

d. Provide general oversight and coordination of the EPSCOR program;

and

c. Provide other such functions as mutually agreed to in writing between the parties. 


\section{N. General Conditions}

1. The University of Kentucky Research Foundation (UKRF) or other such approved entity sball serve (through subcontract) as the fiscal agent for EPSCoR. In this capacity, UKRF or other such approved en tity hall be responsible for receiving, processing and managing EPSCOR funds.

2. EPSCOR shall be subject to the By-laws, policies and procedures of KSTC.

3. The Executive Director of KSTC shall be responsible for the general oversight and overall coordination of EPSCOR activities.

4. There shall be a central project office responsible for the overall coordination of all EPSCOR (i.e., NSF, EPA, DOE, NASA) and related programs.

5. There shall be a "transition committee" established to address issues of mutual concern and to negotiate any conflicts that should arise between the parties. This committee shall consist of six (6) members (three designated by KSTC and three designated by EPSCoR). The Executive Director of KSTC and the Director of the EPSCoR program shall serve as ex-officio non-voting members of the "committee". The initial term of the "transition comnittee" shall be eighteen months. 
6. A member of the EPSCOR Committee shall serve on the KSTC's Executive

Committee.

7. The terms of this Agreement shall be two years, and renewable thereafter. Either party may cancel this Agreement upon 120 days written notice.

8. This Agreement is effective March 1, 1992.

9. This Agreement may be modified in writing by mutual agreement of both parties.

10. This Agreement shall be construed by and governed under the laws of the Commonwealth of Kentucky.

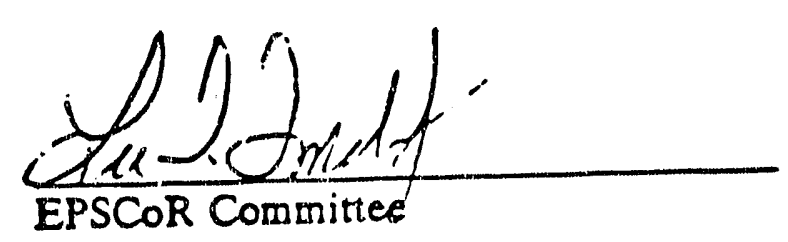

$\frac{21271 \% 2}{\text { Date }}$
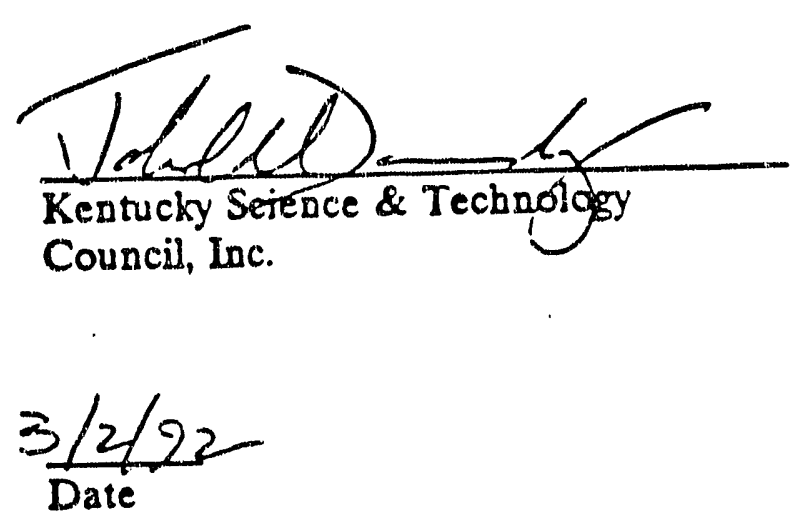

(5) 


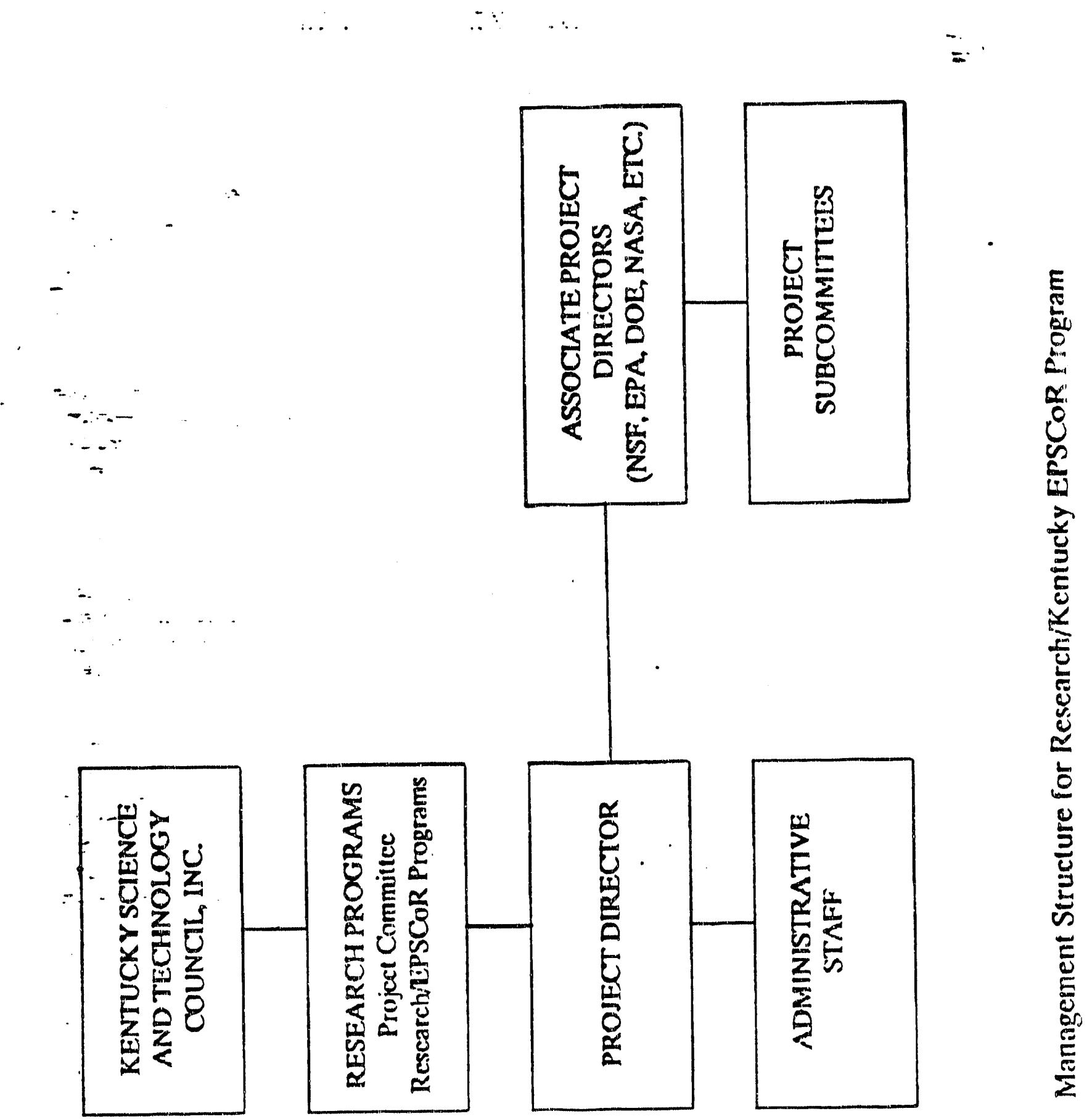



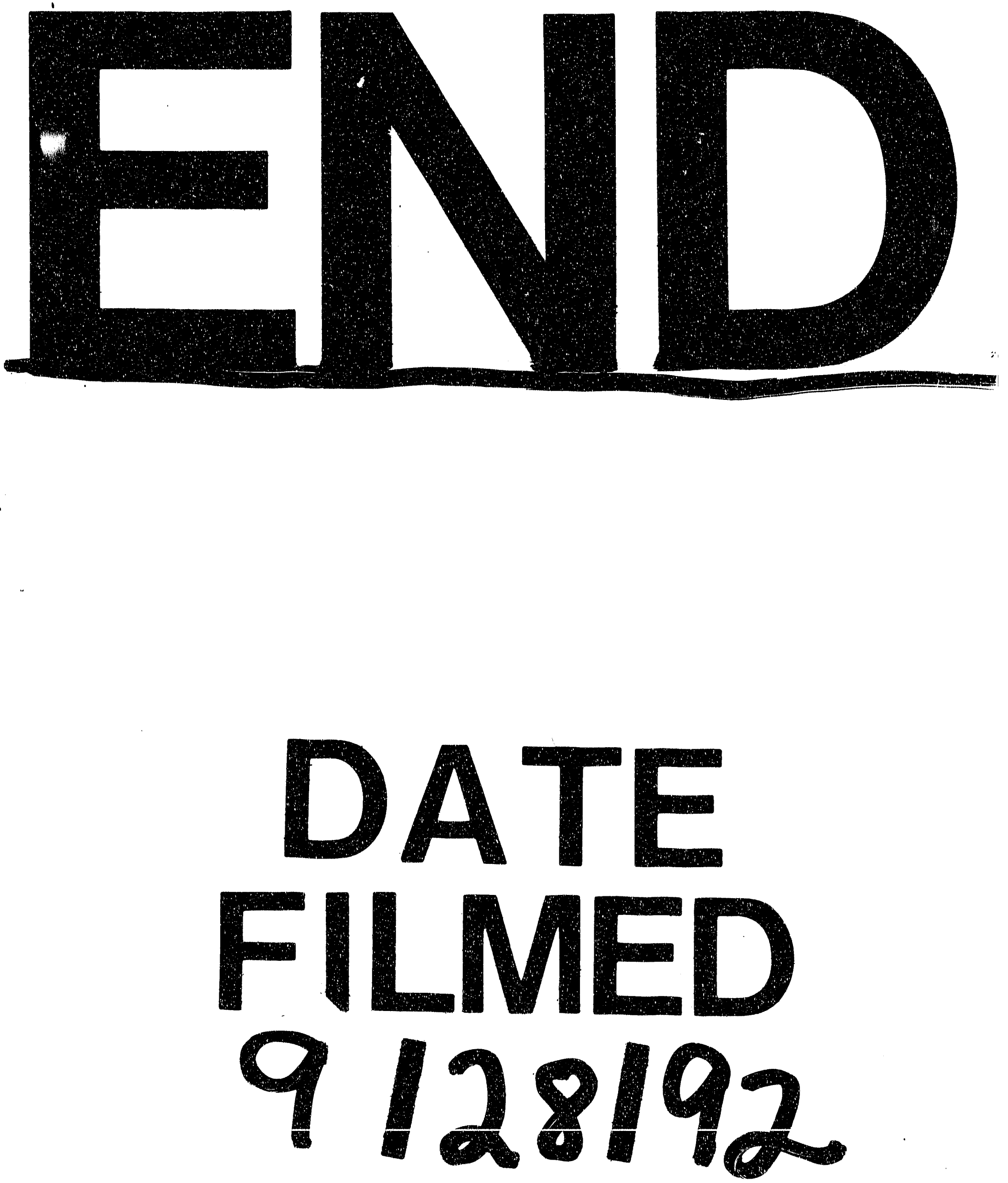
